\title{
Predicting and partitioning ozone fluxes to maize crops from sowing to harvest: the Surfatm-O $\mathbf{O}_{3}$ model
}

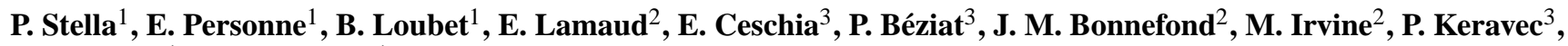 \\ N. Mascher ${ }^{1}$, and P. Cellier ${ }^{1}$ \\ ${ }^{1}$ National Institute for Agronomic Research (INRA), UMR EGC, Thiverval-Grignon, France \\ ${ }^{2}$ National Institute for Agronomic Research (INRA), UR EPHYSE, Villenave d'Ornon, France \\ ${ }^{3}$ CESBIO, UMR 5126 - CNES-CNRS-UPS-IRD- 18 avenue Edouard Belin 31401 Toulouse cedex 9, France
}

Received: 4 July 2011 - Published in Biogeosciences Discuss.: 8 July 2011

Revised: 29 September 2011 - Accepted: 30 September 2011 - Published: 12 October 2011

\begin{abstract}
Terrestrial ecosystems represent a major sink for ozone $\left(\mathrm{O}_{3}\right)$ and also a critical control of tropospheric $\mathrm{O}_{3}$ budget. However, due to its deleterious effects, plant functioning is affected by the ozone absorbed. It is thus necessary to both predict total ozone deposition to ecosystems and partition the fluxes in stomatal and non-stomatal pathways. The Surfatm- $\mathrm{O}_{3}$ model was developed to predict ozone deposition to agroecosystems from sowing to harvest, taking into account each deposition pathways during bare soil, growth, maturity, and senescence periods. An additional sink was added during senescence: stomatal deposition for yellow leaves, not able to photosynthesise but transpiring. The model was confronted to measurements performed over three maize crops in different regions of France. Modelled and measured fluxes agreed well for one dataset for any phenological stage, with only $4 \%$ difference over the whole cropping season. A larger discrepancy was found for the two other sites, $15 \%$ and $18 \%$ over the entire study period, especially during bare soil, early growth and senescence. This was attributed to site-specific soil resistance to ozone and possible chemical reactions between ozone and volatile organic compounds emitted during late senescence. Considering both night-time and daytime conditions, non-stomatal deposition was the major ozone sink, from $100 \%$ during bare soil period to $70-80 \%$ on average during maturity. However, considering only daytime conditions, especially under optimal climatic conditions for plant functioning, stomatal flux could represent $75 \%$ of total ozone flux. This model could improve estimates of crop yield losses and projections of tropospheric ozone budget.
\end{abstract}

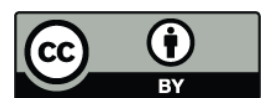

Correspondence to: P. Stella (patrick.stella@grignon.inra.fr)

\section{Introduction}

Ozone $\left(\mathrm{O}_{3}\right)$ in the stratosphere provides protection from solar ultraviolet radiation, but in the troposphere it is a common greenhouse gas, a major pollutant and a powerful oxidant mainly produced via photochemical reactions of nitrogen oxides $\left(\mathrm{NO}_{\mathrm{x}}\right)$ and volatile organic compounds (VOCs). Since the pre-industrial era, mean annual $\mathrm{O}_{3}$ concentrations have increased due to human activities from $10 \mathrm{ppb}$ to between 20 and 45 ppb depending on the geographical location (Vingarzan, 2004). In the next century, $\mathrm{O}_{3}$ concentrations will continue to increase, and Meehl et al. (2007) project an increase of $20-25 \%$ in mean global $\mathrm{O}_{3}$ concentration between 2015 and 2050 and of $40-60 \%$ by 2100 .

Ozone contributes to global warming of the atmosphere by reducing outgoing infrared radiation into space. It is responsible for positive radiative forcing (i.e. heating) estimated to $0.25-0.65 \mathrm{~W} \mathrm{~m}^{-2}$, the strongest after long-lived greenhouse gases $\left(\mathrm{CO}_{2}, \mathrm{CH}_{4}, \mathrm{~N}_{2} \mathrm{O}\right.$ and halocarbons). This accounts for about $25 \%$ of the total net radiative forcing $\left(1.6 \mathrm{~W} \mathrm{~m}^{-2}\right)$ attributed to human activities (Forster et al., 2007). Moreover, $\mathrm{O}_{3}$ is well known to have deleterious effects on materials, human health and plants (PORG, 1997). Indeed, $\mathrm{O}_{3}$ is responsible for damages on polymeric materials such as rubbers, but also on textiles, dyes, surface coatings, metals and buildings materials (Lee et al., 1996; Massey, 1999; Ahmad et al., 2000; Almeida et al., 2000; Boyce et al., 2001) and causes deleterious impacts to human health, including lung inflammation, reduction in lung function, respiratory diseases, and mortality (Rastogi et al., 1991; Uysal and Schapira, 2003; Bell et al., 2005; Ito et al., 2005; Levy et al., 2005; Targer et al., 2005; Hazucha and Lefohn, 2007). On vegetation, $\mathrm{O}_{3}$ slows-down the stomatal closing, decreases

Published by Copernicus Publications on behalf of the European Geosciences Union. 
the photosynthetic capacity and alters plant biomass and leaf area, although these effects depend on species, canopy structure and age of tissues (Paoletti, 2005; Paoletti and Grulke, 2005; Ainsworth, 2008; Wittig et al., 2009). For agroecosystems, current levels of $\mathrm{O}_{3}$ concentration are sufficiently high to reduce yields of crops such as rice, soybean, wheat, potato, and maize, which is a priority issue for food security, and on economic loss of around $\$ 11-\$ 18$ billion annually (Ashmore, 2005; Ashmore et al., 2006; Avnery et al., 2011a). Due to the increase in ozone concentration and its deleterious effect on plants, Avnery et al. (2011b) predict a decrease in world crop yield about $10.6-15.6 \%$ for wheat, $4.5-6.3 \%$ for maize and $12.1-16.4 \%$ for soybean by 2030 , with economical losses about \$12-\$35 billions annually. Finally, recent modelling studies predict a decrease in terrestrial ecosystem $\mathrm{CO}_{2}$ absorption due to $\mathrm{O}_{3}$, which would then affect the atmospheric greenhouse gas budget and enhance global warming (Felzer et al., 2007; Sitch et al., 2007). Providing accurate surface exchange ozone models is a necessity to ameliorate the estimates of the global tropospheric ozone budget (Wild, 2007).

Terrestrial ecosystems are the major sink for ozone. Since $\mathrm{O}_{3}$ is hardly soluble in water, it is deposited mainly through dry deposition (Fowler et al., 2009). In order to quantify the terrestrial ecosystem sink for ozone and to predict the potential effect of ozone on plants, it is necessary (i) on the one hand to predict total ozone deposition to ecosystems and (ii) on the other hand to discriminate the different deposition pathways. To this aim, several studies were performed over forests (Lamaud et al., 2002; Altimir et al., 2004, 2006), crops (Gerosa et al., 2004; Coyle et al., 2009; Lamaud et al., 2009) and grasslands (Zhang et al., 2002, 2006). It is currently assumed that ozone deposition follows stomatal and non-stomatal (i.e. soil and cuticular) pathways. The processes governing each deposition pathways are well identified: stomatal deposition is linked with environmental parameters governing stomatal opening (Emberson et al., 2000a), cuticular deposition increases with relative humidity (Zhang et al., 2002; Altimir et al., 2004, 2006; Coyle et al., 2009; Lamaud et al., 2009) and soil deposition decreases with relative humidity (Stella et al., 2011). Moreover, the partitioning between stomatal, cuticular and soil depositions depends on canopy structure: the ozone transfer from the atmosphere towards the ground is reduced when the canopy height and the leaf area index (LAI) increase (van Pul and Jacobs, 1994; Zhang et al., 2002), while stomatal and cuticular depositions increase with canopy LAI (Zhang et al., 2002; Massman, 2004; Tuovinen et al., 2004).

Ozone deposition over terrestrial ecosystems is usually modelled using resistive schemes with one or two vegetation layers and one soil layer (Wesely, 1989; Wesely and Hicks, 2000). However, these models differ from resistance parameterisations, especially concerning non-stomatal resistances for which there is no consensus (Zhang et al., 2002; Bassin et al., 2004; Lamaud et al., 2009; Tuzet et al., 2011). Moreover, current models are usually used for fully developed canopies. In these cases, soil and cuticular pathways could probably compensate each other and the partitioning of non-stomatal deposition is uncertain. Finally, non-stomatal resistances, in particular cuticular resistance, are expressed as functions of air climatic variables (such as air relative humidity) and not as a function of climatic variables at the leaf surface. This issue could have a strong impact especially during growing season when the difference between measurement and canopy heights changes, leading to differences between relative humidity at the measurement height and the leaf surface.

This paper presents the Surfatm- $\mathrm{O}_{3}$ model, a soilvegetation-atmosphere-transfer model combining a resistive approach for heat and ozone, parameterised for maize canopies and taking into account bare soil, growth, maturity and senescence periods. It incorporates stomatal pathway for green and yellow leaves, soil and cuticular pathways. This model was developed for a maize canopy in Grignon, 40 kilometres west of Paris using parameterisation for soil and cuticular resistances obtained on the same site. It is then tested against measurements performed over two maize crops in southern France. In addition, the sensitivity of the model is presented. Finally, the model is used to partition total ozone flux for each site and the contribution of each deposition pathway along the whole cropping period is analysed.

\section{Surfatm- $\mathrm{O}_{3}$ model description}

The Surfatm- $\mathrm{O}_{3}$ model is a one dimensional soil-vegetationatmosphere-transfer model, elaborated upon the model described in Personne et al. (2009), which includes (i) an energy budget model accounting for the latent (LE) and sensible $(H)$ heat fluxes and (ii) a pollutant exchange model simulating ozone fluxes between the surface and the atmosphere. It includes one vegetation layer and one soil compartment. The model is based on the same resistive scheme for the energy balance and the $\mathrm{O}_{3}$ exchange, meaning with the same aerodynamic, quasi-laminar boundary layer and stomatal resistances, the two latter being modulated by the scalar diffusivities. The energy balance and $\mathrm{O}_{3}$ exchange models are coupled through leaf temperature $\left(T_{z_{0}^{\prime}}\right)$, leaf water vapour partial pressure $\left(e_{z_{0}^{\prime}}\right)$, soil surface temperature $\left(T_{\text {surf }}\right)$, and soil water vapour partial pressure $\left(e_{\text {surf }}\right)$ allowing to calculate cuticular and soil resistances.

The energy balance model, its input parameters and the transfer resistances (aerodynamic resistance $\left(R_{\mathrm{a}}\right)$, in-canopy aerodynamic resistance $\left(R_{\mathrm{ac}}\right)$, leaf quasi-laminar boundary layer resistance $\left(R_{\mathrm{bl}}\right)$ and soil quasi-laminar boundary layer resistance $\left.\left(R_{\mathrm{bs}}\right)\right)$ are fully described in Personne et al. (2009) and will not be detailed in the following. The resistive scheme for $\mathrm{O}_{3}$ is shown in Fig. 1. 


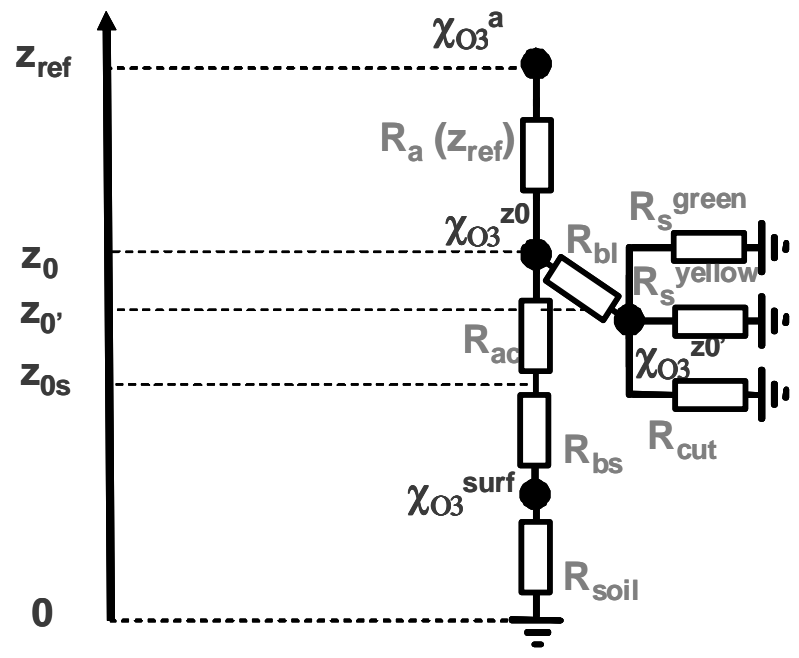

Fig. 1. Resistive scheme for $\mathrm{O}_{3}$ exchange model. $z$ is the height above ground; $R_{\mathrm{a}}, R_{\mathrm{ac}}, R_{\mathrm{bl}}, R_{\mathrm{bs}}, R_{\mathrm{soil}}, R_{\mathrm{cut}}, R_{\mathrm{S}}^{\text {green }}$, and $R_{\mathrm{S}}^{\text {yellow }}$ are aerodynamic resistance, in-canopy aerodynamic resistance, leaf quasi-laminar boundary layer resistance, soil quasi-laminar boundary layer resistance, soil resistance, cuticular resistance, green leaf stomatal resistance, and yellow leaf stomatal resistance respectively; $\chi_{\mathrm{O}_{3}}$ is the ozone concentration; indexes ref, $a, z_{0}, z_{0^{\prime}}$, and $z_{0 \mathrm{~s}}$ refer to reference, atmospheric, canopy roughness height for momentum, canopy roughness height for scalar, and soil roughness height respectively.

\subsection{Soil resistance}

The soil resistance ( $R_{\text {soil }}$ in $\mathrm{s} \mathrm{m}^{-1}$ ) is calculated using the parameterisation obtained by Stella et al. (2011) on the Grignon site as:

$R_{\text {soil }}=R_{\text {soil }_{\min }} * e^{\left(k_{\text {soil }} \times \mathrm{RH}_{\text {surf }}\right)}$

where $R_{\text {soil }_{\text {min }}}\left(=21.15 \mathrm{~s} \mathrm{~m}^{-1}\right)$ is the soil resistance without water adsorbed at the soil surface (i.e. at $\mathrm{RH}_{\text {surf }}=0 \%$ ), $k_{\text {soil }}(=0.024)$ is an empirical coefficient of the exponential function and $\mathrm{RH}_{\text {surf }}$ is the soil surface relative humidity estimated with $T_{\text {surf }}$ and $e_{\text {surf from energy balance model. }}$

\subsection{Cuticular resistance}

The cuticular resistance $\left(R_{\text {cut }}\right.$ in $\left.\mathrm{s} \mathrm{m}^{-1}\right)$ is parameterised following Lamaud et al. (2009) as a function of relative humidity obtained for maize crop at maturity on Grignon site, and total Leaf Area Index ( $\mathrm{LAI}_{\text {tot }}$ ) (Massman, 2004). The parameterisation proposed in Lamaud et al. (2009) is a function of air relative humidity at reference height. However the relative humidity at the leaf surface $\left(\mathrm{RH}_{z_{0}^{\prime}}\right)$ is used in the Surfatm- $\mathrm{O}_{3}$ model to take into account the change in measurement height minus displacement height along the growing season. In addition, Lamaud et al. (2009) do not express the variability in crop phenology but indicate an equivalence with Massman (2004) who takes into account variations in canopy structure. The cuticular resistance is expressed combining the expressions of Massman (2004) and Lamaud et al. (2009) as:

$R_{\text {cut }}=R_{\text {cut }_{\text {max }}}$ if $\mathrm{RH}_{z_{0}^{\prime}}<\mathrm{RH}_{0}$

$R_{\mathrm{cut}}=R_{\mathrm{cut}_{\max }} * e^{\left(-k_{\mathrm{cut}} \cdot\left(\mathrm{RH}_{z_{0}^{\prime}}-\mathrm{RH}_{0}\right)\right)}$ if $\mathrm{RH}_{z_{0}^{\prime}}>\mathrm{RH}_{0}$

where $R_{\text {cut }_{\max }}\left(=5000 / \mathrm{LAI}_{\text {tot }}\right)$ is the maximal cuticular resistance calculated as Massman (2004), $\mathrm{RH}_{0}(=60 \%)$ is a threshold value of the relative humidity and $k_{\text {cut }}(=0.045)$ is an empirical coefficient of the exponential function taken from Lamaud et al. (2009).

\subsection{Stomatal resistance}

The stomatal resistance is based on a multiplicative model that describes leaf stomatal conductance as a function of plant species and environmental variables (leaf temperature $\left(T_{z_{0}^{\prime}}\right)$, photosynthetically active radiation (PAR), leafto-air vapour pressure deficit (VPD) and soil water potential $(\mathrm{SWP}))$. The leaf stomatal resistance $\left(R_{\mathrm{s}}^{\text {leaf }}\right.$ in $\left.\mathrm{s} \mathrm{m}^{-1}\right)$ is calculated following Emberson et al. (2000b) and Tuovinen et al. (2004) as:

$R_{\mathrm{S}}^{\text {leaf }}=\left[\left(g_{\max } * g_{\mathrm{PAR}} * \max \left\{g_{\min },\left(g_{\mathrm{T}} * g_{\mathrm{VPD}} * g_{\mathrm{SWP}}\right)\right\}\right) / 41000\right]^{-1}$

where $g_{\max }$ (in mmol m $\mathrm{m}^{-2} \mathrm{~s}^{-1}$ ) is the maximum leaf stomatal conductance, $g_{\mathrm{PAR}}, g_{\mathrm{T}}, g_{\mathrm{VPD}}$, and $g_{\mathrm{SWP}}$ represent the response of $g_{\max }$ to PAR, leaf temperature, VPD and SWP respectively, $g_{\min }$ is the minimum stomatal conductance that occurs during the daylight period and 41000 is the factor to convert mmol m $\mathrm{m}^{-2} \mathrm{~s}^{-1}$ to $\mathrm{m} \mathrm{s}^{-1}$ (Jones, 1992). The generic function $g_{\mathrm{PAR}}, g_{\mathrm{T}}, g_{\mathrm{VPD}}$, and $g_{\mathrm{SWP}}$ are species specific. The parameterisations for each function are indicated in Table 1 using coefficients from Emberson et al. (2000b).

The up-scaling from leaf to canopy stomatal resistance is carried out by dividing leaf stomatal resistance by leaf area index (Emberson et al., 2000b; Tuovinen et al., 2004). However, all the leaves do not contribute in the same extend to canopy stomatal resistance due to vertical structure of the canopy influencing environmental conditions inside the canopy such as solar radiation. To take into account this issue, the up-scaling from leaf to canopy is performed using effective leaf area index $\left(\mathrm{LAI}_{\mathrm{e}}\right)$ instead of $\mathrm{LAI}$ as proposed by Rochette et al. (1991).

In the present model, we dissociate stomatal resistance for green leaves (able to photosynthesise) $\left(R_{\mathrm{S}}^{\text {green }}\right)$ and yellow leaves (not able to photosynthesise but transpiring) $\left(R_{\mathrm{S}}^{\text {yellow }}\right)$ by dividing leaf stomatal resistance by effective green leaf area index $\left(\mathrm{LAI}_{\mathrm{e}}^{\text {green }}\right)$ and effective yellow leaf area index $\left(\mathrm{LAI}_{\mathrm{e}}^{\text {yellow }}\right.$, obtained by difference between maximal leaf area index of the cropping season and green leaf area index) respectively: 


$$
\begin{aligned}
& R_{\mathrm{S}}^{\text {green }}=R_{\mathrm{S}}^{\text {leaf }} / L A I_{\mathrm{e}}^{\text {green }} \\
& R_{\mathrm{S}}^{\text {yellow }}=R_{\mathrm{S}}^{\text {leaf }} / \mathrm{LAI}_{\mathrm{e}}^{\text {yellow }}
\end{aligned}
$$

\subsection{Modelling ozone deposition velocity and flux}

Following the resistance analogy (Wesely and Hicks, 2000), the ozone deposition velocity is expressed by analogy with the Ohm's law. The leaf resistance at $z_{0}^{\prime}$ (the canopy roughness height for scalar) $\left(R_{z_{z_{0}^{\prime}}}\right)$ is determined as:

$\frac{1}{R_{z_{0}^{\prime}}}=\frac{1}{R_{\text {cut }}}+\frac{1}{R_{\mathrm{s}}^{\text {green }}}+\frac{1}{R_{\mathrm{S}}^{\text {yellow }}}$

The leaf resistance at $z_{0}$ (the canopy roughness height for momentum) $\left(R_{\mathrm{I}_{z 0}}\right)$ is calculated as:

$R_{\mathrm{l} 0}=R_{\mathrm{bl}}+R_{\mathrm{z}_{0}^{\prime}}$

The resistance to ground deposition ( $\left.R_{\text {ground }}\right)$ is obtained as:

$$
R_{\text {ground }}=R_{\mathrm{ac}}+R_{\mathrm{bs}}+R_{\text {soil }}
$$

The canopy resistance $\left(R_{\mathrm{C}}\right)$ is defined as:

$\frac{1}{R_{\mathrm{c}}}=\frac{1}{R_{\text {ground }}}+\frac{1}{R_{\mathrm{l}_{z}}}$

Ozone deposition velocity $\left(V_{\mathrm{d}}\right)$ at reference height $\left(z_{\text {ref }}\right)$ and ozone flux $\left(F_{\mathrm{O} 3}\right)$ are finally calculated as:

$V_{\mathrm{d}}\left(z_{\text {ref }}\right)=\frac{1}{R_{\mathrm{a}}\left(z_{\text {ref }}\right)+R_{\mathrm{c}}}$

$F_{\mathrm{O}_{3}}=-V_{\mathrm{d}}\left(z_{\mathrm{ref}}\right) * \chi_{\mathrm{O}_{3}}^{a}$

where $\chi_{\mathrm{O} 3}^{a}$ is the ozone concentration at the reference height.

\section{Materials and methods}

\subsection{Site characteristics and measurements}

The Grignon, La Cape Sud and Lamasquère sites and measurements for each site are fully described in Loubet et al. (2011), Stella et al. (2009) and Béziat et al. (2009) respectively. The Grignon site $\left(48^{\circ} 51^{\prime} \mathrm{N}, 1^{\circ} 58^{\prime} \mathrm{E}\right)$ is a $19 \mathrm{ha}$ field located at $40 \mathrm{~km}$ west of Paris, France. It is surrounded by roads on the East, South and South-West. The soil is a silt loam. In 2008, the field was sown with maize (NK Perform) used for silage. The parcel was not irrigated. The experiment was carried out from maize sowing, 28 April 2008, to the harvest (9 September 2008).

The experimental site of La Cape Sud $\left(44^{\circ} 24^{\prime} \mathrm{N}, 0^{\circ} 38^{\prime} \mathrm{W}\right)$ is located at $60 \mathrm{~km}$ south of Bordeaux, France. The soil is sandy with a dark organic matter layer in the first $0.4 \mathrm{~m}$. In 2007, the 20 ha field was sown with maize. The field was irrigated regularly from July to August by two ramps. The dataset begins on 26 July 2007 during maize maturity and lasts until maize harvest, 11 October 2007.
Table 1. Parameterisations used in the stomatal resistance model. PAR is the photosynthetically active radiation $\left(\mu \mathrm{mol} \mathrm{m}^{-2} \mathrm{~s}^{-1}\right)$,

\begin{tabular}{|c|c|}
\hline Name & Parameterisation \\
\hline$g_{\max }$ & $\begin{array}{l}156 \mathrm{mmol} \mathrm{O}_{3} \mathrm{~m}^{-2} \mathrm{~s}^{-1}(= \\
\left.236 \mathrm{mmol} \mathrm{H}_{2} \mathrm{O} \mathrm{m}^{-2} \mathrm{~s}^{-1}\right)\end{array}$ \\
\hline$g_{\min }$ & 0.19 \\
\hline$g_{\mathrm{PAR}}$ & $\begin{array}{l}1-e^{(-\alpha * \mathrm{PAR})} \\
\text { with } \alpha=0.0048\end{array}$ \\
\hline$g_{\mathrm{T}}$ & $\begin{array}{l}\text { If } T_{z_{0}^{\prime}}<T_{\min }, g_{\mathrm{T}}=g_{\min } ; \\
\text { If } T_{z_{0}^{\prime}}>T_{\max }, g_{\mathrm{T}}=g_{\min } ; \\
\text { If } T_{\min }<T_{z_{0}^{\prime}}<T_{\max }, g_{\mathrm{T}}=1-\left(\frac{T_{z_{0}^{\prime}}-T_{\mathrm{opt}}}{T_{\mathrm{opt}}-T_{\min }}\right)^{2} ; \\
\text { with } T_{\min }=0^{\circ} \mathrm{C}, T_{\mathrm{opt}}=25^{\circ} \mathrm{C} \text { and } T_{\max }=51^{\circ} \mathrm{C} \text {. }\end{array}$ \\
\hline$g_{\mathrm{VPD}}$ & $\begin{array}{l}\text { If } \mathrm{VPD}<\mathrm{VPD}_{\max }, g_{\mathrm{VPD}}=1 ; \\
\text { If } \mathrm{VPD}>\mathrm{VPD}_{\min }, \mathrm{g}_{\mathrm{VPD}}=\mathrm{g}_{\min } ; \\
\text { If } \mathrm{VPD}_{\min }<\mathrm{VPD}<\mathrm{VPD}_{\max }, \\
g_{\mathrm{VPD}}=\left(\frac{1-g_{\min }}{\mathrm{VPD}_{\max }-\mathrm{VPD}_{\min }}\right) * \mathrm{VPD}+g_{\min }- \\
\left(\frac{1-g_{\min }}{\mathrm{VPD}_{\max }-\mathrm{VPD}_{\min }}\right) * \mathrm{VPD}_{\min } ; \\
\text { with } \mathrm{VPD}_{\min }=2.5 \mathrm{kPa} \text { and } \mathrm{VPD}_{\max }=1 \mathrm{kPa} .\end{array}$ \\
\hline$g_{\mathrm{SWP}}$ & $\begin{array}{l}\text { If } \mathrm{SWP}>\mathrm{SWP} \text { min } \\
\text { If } g_{\mathrm{SWP}}=1 ; \\
\text { If } \mathrm{SWP}_{\min }<\mathrm{SWP}_{\max }, g_{\mathrm{SWP}}=g_{\min } ; \\
g_{\mathrm{SWP}}=\left(\frac{1-\mathrm{SWP}_{\max }}{\mathrm{SWP}_{\min }-\mathrm{SWP}_{\max }}\right) * \mathrm{SWP}+g_{\min }- \\
\left(\frac{1-g_{\min }}{\mathrm{SWP}_{\min }-\mathrm{SWP}_{\max }}\right) * \mathrm{SWP}_{\max } ; \\
\text { with SWP }_{\min }=-0.11 \mathrm{MPa} \text { and } \\
\mathrm{SWP}_{\max }=-0.8 \mathrm{MPa} \text {. }\end{array}$ \\
\hline
\end{tabular}
VPD is the leaf vapour pressure deficit $(\mathrm{kPa}), T_{z_{0}^{\prime}}$ is the leaf temperature $\left({ }^{\circ} \mathrm{C}\right)$, and SWP is the soil water deficit (MPa).

The Lamasquère site $\left(43^{\circ} 49^{\prime} \mathrm{N}, 1^{\circ} 23^{\prime} \mathrm{E}\right)$ is located at $20 \mathrm{~km}$ south-west of Toulouse, France. The soil is a loam. This 32 ha field was sown with maize for silage (PR35A30) on 20 May 2008 and harvested the 11 September 2008. The field was irrigated from July to August. The dataset covers sowing to harvest.

For each site, standard meteorological variables were recorded. These measurements included global $\left(R_{\mathrm{g}}\right)$ and net radiation $\left(R_{\mathrm{n}}\right)$, incoming photosynthetic photon flux density (PPFD), air temperature $\left(T_{\mathrm{a}}\right)$ and relative humidity $(\mathrm{RH})$, soil temperature $\left(T_{\text {soil }}\right)$, soil water content (SWC), wind speed $(U)$, wind direction (WD) and rainfall. In addition, measurements of leaf area index (LAI) and canopy height $\left(h_{\mathrm{c}}\right)$ were carried out occasionally for La Cape Sud and Lamasquère sites while they were modelled with CERESEGC model (Lehuger et al., 2010) for the Grignon site.

Turbulent fluxes of momentum $(\tau)$, sensible heat $(H)$, latent heat (LE), $\mathrm{CO}_{2}\left(F_{\mathrm{CO}_{2}}\right)$ and $\mathrm{O}_{3}\left(F_{\mathrm{O}_{3}}\right)$ were measured by eddy covariance, with the sonic anemometer and the gas 
sampling at $3.4 \mathrm{~m}, 6.4 \mathrm{~m}$ and $3.65 \mathrm{~m}$ for Grignon, La Cape Sud and Lamasquère respectively. Specifically for ozone flux, the ratio method described in Muller et al. (2010) which provided measurements of deposition velocity (the flux divided by concentration) owing to the very small and constant offset of the fast ozone analyser (ATDD, NOAA, USA), was applied. The ozone flux was obtained by multiplying the deposition velocity by the absolute ozone concentration measured with slow response sensor (Environnement SA, model $41 \mathrm{M}$, France). Fluxes were integrated over $30 \mathrm{~min}$ time spans and calculation followed the CarboEurope methodology (Aubinet et al., 2000).

\subsection{Stomatal conductance deduced from measurements}

The stomatal conductance for $\mathrm{O}_{3}\left(g_{\mathrm{s}}\right.$, the inverse of stomatal resistance $R_{\mathrm{S}}$ ) can be deduced from water vapour flux measurements by inverting the Penman-Monteith equation (Monteith, 1981):

$g_{\mathrm{SPM}}=\frac{D_{\mathrm{O}_{3}}}{D_{\mathrm{H}_{2} \mathrm{O}}} * \frac{\frac{E}{\delta_{\mathrm{w}}}}{1+\frac{E}{\delta_{\mathrm{w}}}\left(R_{\mathrm{a}}+R_{\mathrm{b}}\right)\left(\frac{\beta \mathrm{s}}{\gamma}-1\right)}$

where $D_{\mathrm{O}_{3}}$ and $D_{\mathrm{H}_{2} \mathrm{O}}\left(\mathrm{m}^{2} \mathrm{~s}^{-1}\right)$ are molecular diffusivities for $\mathrm{O}_{3}$ and $\mathrm{H}_{2} \mathrm{O}$ respectively $\left(D_{\mathrm{O}_{3}} / D_{\mathrm{H}_{2} \mathrm{O}} \approx 0.66\right), E$ is the water vapour flux $\left(\mathrm{kg} \mathrm{m}^{-2} \mathrm{~s}^{-1}\right), \delta_{\mathrm{w}}$ the water vapour density saturation deficit $\left(\mathrm{kg} \mathrm{m}^{-3}\right), \beta$ the Bowen ratio, $s$ the slope of the saturation curve $\left(\mathrm{K}^{-1}\right)$ and $\gamma$ the psychrometric constant $\left(\mathrm{K}^{-1}\right)$.

This estimation of $g_{\mathrm{s}}$ requires that $E$ represents only plant transpiration without including soil evaporation and evaporation of liquid water (rain, dew) which may be present at the canopy surface. This estimation of stomatal conductance was corrected for water evaporation as proposed by Lamaud et al. (2009): for dry conditions ( $\mathrm{RH}<60 \%$, for which liquid water at the leaf surface is considered as completely evaporated) $g_{\mathrm{SPM}}$ is plotted against Gross Primary Production (GPP, estimated on a daily basis following Kowalski et al., 2003, 2004). The corrected stomatal conductance $\left(g_{\mathrm{s}_{\text {corr }}}\right)$ for all humidity conditions is then given by:

$g_{\mathrm{scorr}}=\alpha * \mathrm{GPP}$

where $\alpha$ is the slope of $g_{\mathrm{SPM}}=f(\mathrm{GPP})$ relationship in dry conditions.

\section{Results and discussion}

\subsection{Overview on meteorological conditions, crop phenology and ozone deposition}

Meteorological conditions for the three sites were contrasted during the experimental period. Daily arithmetic means of the main climatic variables are shown in Fig. 2a-e. Although day-to-day and month-to-month variations of the climatic
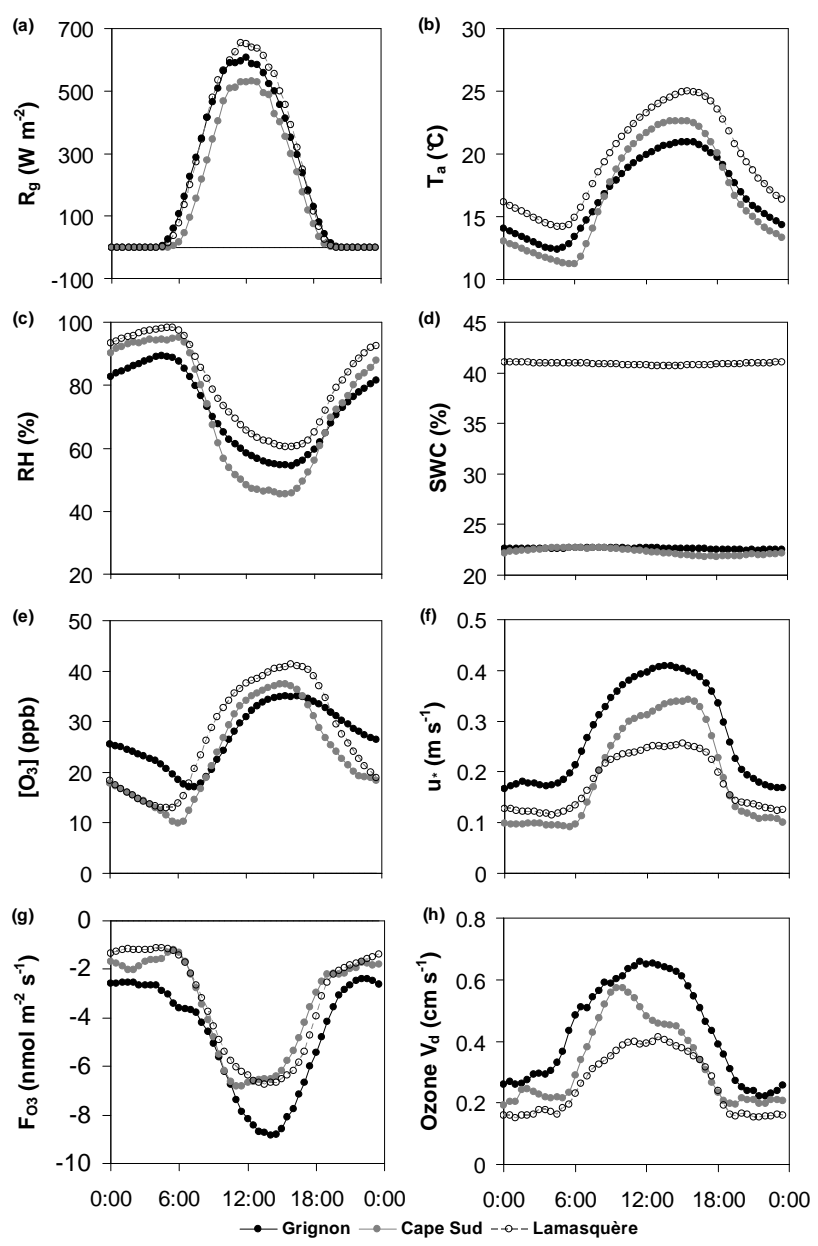

Fig. 2. Half hourly arithmetic means of (a) global radiation, (b) air temperature, (c) air relative humidity, (d) soil water content, (e) $\mathrm{O}_{3}$ concentration, (f) friction velocity, (g) $\mathrm{O}_{3}$ flux, and (h) $\mathrm{O}_{3}$ deposition velocity. Black, grey and open symbols are data from Grignon, La Cape Sud and Lamasquère respectively.

conditions can be large, some differences between each site appear in the half-hourly means.

The Grignon site was characterised by intermediate meteorological conditions compared to the two other sites. Global radiation reached $600 \mathrm{~W} \mathrm{~m}^{-2}$ at noon (Fig. 2a) and relative humidity decreased to $55 \%$ during early afternoon (Fig. 2c). Air temperature was the lowest with only $20^{\circ} \mathrm{C}$ in average during daytime (Fig. 2b). Mean soil water content was around $22.5 \%$ for the whole period (Fig. 2d). However, the SWC varied during the cropping period due to maize establishment: SWC was constant from April 2008 to mid June 2008, around $27 \%$, decreased to $17 \%$ until the end of July and was constant until the maize harvest. Ozone concentration was around 20-25 ppb during nighttime and increased to around $35 \mathrm{ppb}$ during early afternoon (Fig. 2e). Friction velocity was the strongest of the three sites with mean maximal daytime values of $0.4 \mathrm{~m} \mathrm{~s}^{-1}$ and nighttime 
values around $0.17 \mathrm{~m} \mathrm{~s}^{-1}$ (Fig. 2f). The maize emerged the 11 May 2008. The growth lasted until 29 June 2008 and the maize reached maximum height and LAI of about $2.2 \mathrm{~m}$ and $5.2 \mathrm{~m}^{2} \mathrm{~m}^{-2}$, respectively. The first yellow leaves appeared around the 11 July 2008 and their LAI increased to a maximum around $3.6 \mathrm{~m}^{2} \mathrm{~m}^{-2}$ when the maize was harvested on 9 September 2008 (Table 2).

For the La Cape Sud site, mean global radiation reached only $500 \mathrm{~W} \mathrm{~m}^{-2}$ (Fig. 2a), but this was mainly due to seasonal decrease in $R_{\mathrm{g}}$, since this dataset extended to October 2007. Air mean temperature ranged from $12^{\circ} \mathrm{C}$ during nighttime to $22^{\circ} \mathrm{C}$ during daytime (Fig. 2b). Air relative humidity was the lowest and decreased to $45 \%$ during daytime (Fig. 2c). Soil water content was in mean similar to those of Grignon site, around $22.5 \%$ for the entire period (Fig. 2d). However, as for Grignon site, SWC was highly variable. From July to August 2007, irrigation allowed maximal SWC, around $40 \%$, although there was a fast decrease due to the soil texture (i.e. composed mainly by sand). When the irrigation stopped in early September 2007, SWC rapidly decreased to its minimum around $10 \%$. Ozone concentration ranged from $10 \mathrm{ppb}$ during nighttime to $37 \mathrm{ppb}$ in early afternoon (Fig. 2e). Friction velocity varied between $0.1 \mathrm{~m} \mathrm{~s}^{-1}$ during nighttime and $0.35 \mathrm{~m} \mathrm{~s}^{-1}$ during daytime (Fig. 2f). The dataset started during maize maturity. The maize height was $2.5 \mathrm{~m}$ and the LAI of green leaves was $5.1 \mathrm{~m}^{2} \mathrm{~m}^{-2}$. The first yellow leaves appeared around the 1 August 2007. All leaves were yellow when the maize was harvested the 11 October 2007 (Table 2).

The Lamasquère site was the warmest with air temperature ranging from $15^{\circ} \mathrm{C}$ during nighttime to $25^{\circ} \mathrm{C}$ during daytime (Fig. 2b). Global radiation reached $650 \mathrm{~W} \mathrm{~m}^{-2}$ at noon (Fig. 2a) and air relative humidity decreased to $60 \%$ during early afternoon (Fig. 2c). The water supply provided by irrigations allowed constant SWC, around $40 \%$ (Fig. 2d), over the entire cropping period. Ozone concentration increased to reach its maximum, around $40 \mathrm{ppb}$, during mid afternoon and decreased to $15-20 \mathrm{ppb}$ during nighttime (Fig. 2e). Friction velocity reached $0.25 \mathrm{~m} \mathrm{~s}^{-1}$ during daytime, which represents the lowest $u_{*}$, and decreased to $0.12 \mathrm{~m} \mathrm{~s}^{-1}$ during nighttime (Fig. 2f). The maize sown the 20 May 2008 emerged the 29 May 2008. The growing period was the longest and lasted until the 29 July 2008 approximately. The field was harvested before the first yellow leaves appeared the 11 September 2008. Maximal canopy height was similar to those of the other site, $2.5 \mathrm{~m}$ height, while LAI was the lowest, only $3.2 \mathrm{~m}^{2} \mathrm{~m}^{-2}$ (Table 2).

Half-hourly means of ozone deposition velocities for each site are indicated in Fig. $2 \mathrm{~h}$. The values of ozone $V_{\mathrm{d}}$ were highly different according to site: they reached $0.65 \mathrm{~cm} \mathrm{~s}^{-1}$ for Grignon site, $0.57 \mathrm{~cm} \mathrm{~s}^{-1}$ for La Cape Sud site and only $0.41 \mathrm{~cm} \mathrm{~s}^{-1}$ for Lamasquère site. For Grignon and Lamasquère sites, ozone $V_{\mathrm{d}}$ increased to reach a peak at noon and then decreased to its minimum during nighttime. Concerning La Cape Sud site, dynamics of ozone $V_{\mathrm{d}}$ was slightly different: deposition velocity reached its maximum during mid morning and suddenly decreased to $0.45 \mathrm{~cm} \mathrm{~s}^{-1}$ at noon. Then ozone $V_{\mathrm{d}}$ decreased once again during mid afternoon to its minimum as for the two others sites (Fig. 2h).

The ozone fluxes were similar for $\mathrm{La}$ Cape Sud and Lamasquère: they were at a minimum, around $-1.2 \mathrm{nmol} \mathrm{m}^{-2} \mathrm{~s}^{-1}$, during nighttime and increased to reach a maximum around $-7 \mathrm{nmol} \mathrm{m}{ }^{-2} \mathrm{~s}^{-1}$ during early afternoon. The ozone flux for Grignon site was the greatest with minimal ozone flux around $-2.5 \mathrm{nmol} \mathrm{m}^{-2} \mathrm{~s}^{-1}$ and reached $-9 \mathrm{nmol} \mathrm{m}^{-2} \mathrm{~s}^{-1}$ (Fig. 2g). These values were similar to ozone fluxes reported by several authors over various ecosystems. Gerosa et al. (2005), Vitale et al. (2005), Cieslik (2009), and Fares et al. (2010) reported ozone fluxes ranging from 0 to $-12 \mathrm{nmol} \mathrm{m}^{-2} \mathrm{~s}^{-1}$ for forest ecosystems. In addition, Grantz et al. (1995, 1997) reported ozone fluxes around $-6 \mathrm{nmol} \mathrm{m}^{-2} \mathrm{~s}^{-1}$ and $-10 \mathrm{nmol} \mathrm{m}^{-2} \mathrm{~s}^{-1}$ for grape and cotton fields respectively. Gerosa et al. (2007) found that maximal ozone fluxes varied between $-5 \mathrm{nmol} \mathrm{m}^{-2} \mathrm{~s}^{-1}$ and $-40 \mathrm{nmol} \mathrm{m}^{-2} \mathrm{~s}^{-1}$ for onion field and Coyle et al. (2009) measured average ozone fluxes of $-9.5 \mathrm{nmol} \mathrm{m}^{-2} \mathrm{~s}^{-1}$ for potato canopy. Similar fluxes, ranging from 0 to $-20 \mathrm{nmol} \mathrm{m}^{-2} \mathrm{~s}^{-1}$, were reported by Gerosa et al. (2004) over barley field and by Bassin et al. (2004) and Tuzet et al. (2011) for wheat crops. Thus, ozone fluxes in this study can be assumed as standard and do not represent exceptional conditions.

\subsection{Surfatm- $\mathrm{O}_{3}$ model test against the Grignon site data}

The aim of this study was not developing an energy balance model, as this work was already done in Personne et al. (2009). Thus, this issue will not be detailed in the following. It is however interesting to note that along the whole cropping season for the Grignon site the modelled and measured LE agreed well, only $8 \%$ difference $\left(R^{2}=0.70\right)$, indicating that transfer resistances were well modelled.

The model was tested against measurements of ozone deposition performed in the Grignon site. Although the model was partially built using parameterizations obtained on the same site, they were not necessarily obtained using the dataset presented here and significantly modified. Indeed, the parameterization of $R_{\text {soil }}$ was established by including other datasets from Grignon in 2007 and 2008 (Stella et al., 2011). In addition, the parameterization of $R_{\text {cut }}$ proposed by Lamaud et al. (2009) was obtained for an other maize crop in another field in Grignon in 2002. This parameterization was further modified to be expressed as a function of relative humidity at the leaf surface instead of relative humidity at the reference height and to take into account the evolution of leaf area index along the cropping season (see Sect. 2.2).

The modelled ozone deposition velocity agreed well with measurements and reproduced diurnal and day-to-day variations of measured ozone $V_{\mathrm{d}}$ from sowing to harvest, i.e. including bare soil, growth maturity and senescence (Fig. 3). 

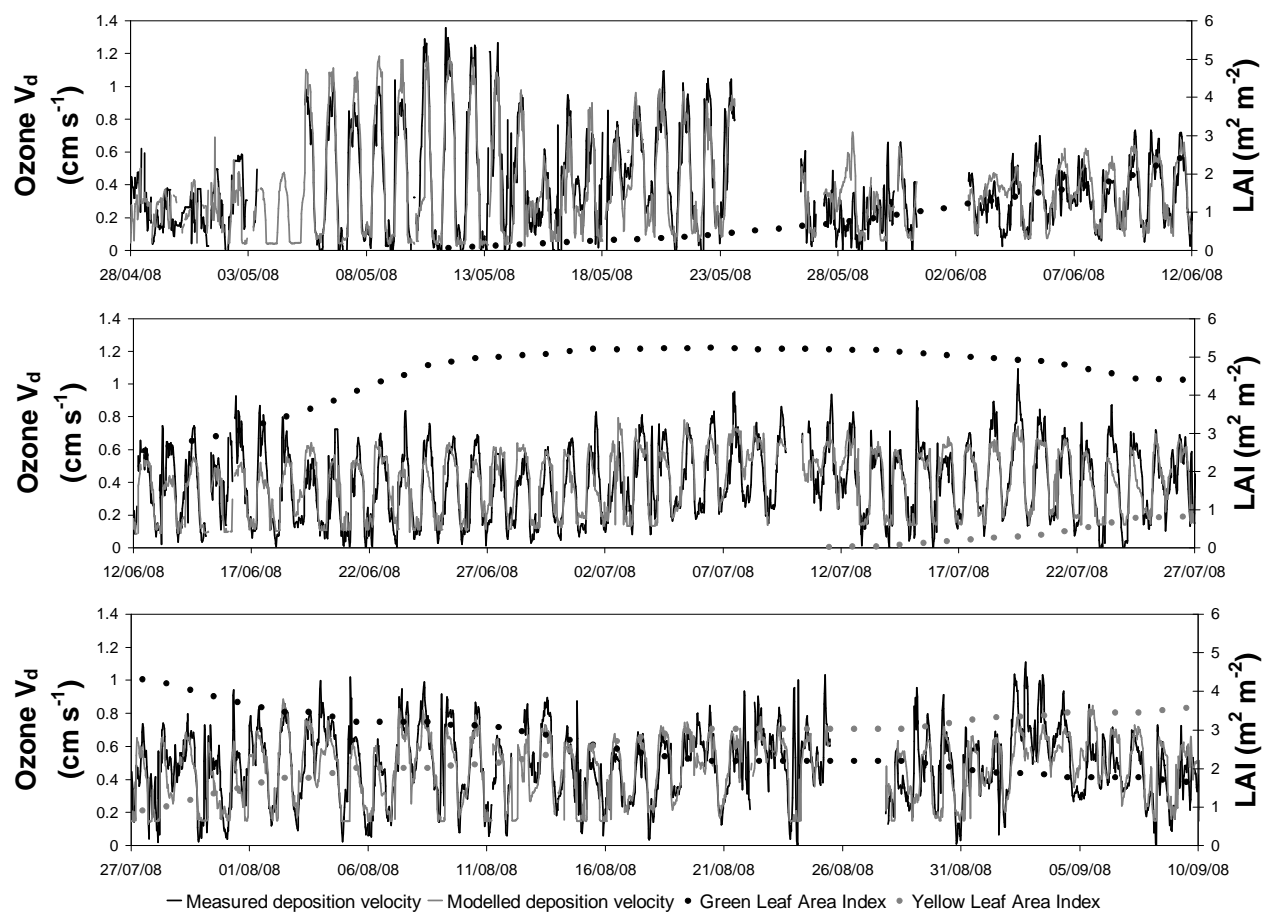

Fig. 3. Time series of measured (black line) and modelled (grey line) ozone deposition velocities for the Grignon site from sowing (i.e. the 28 April 2008) to harvest (i.e. the 9 September 2008). Black and grey circles are Leaf Area Index for green and yellow leaves respectively.

Table 2. Phenological stages of maize for Grignon, La Cape Sud and Lamasquère sites during the study periods.

\begin{tabular}{lccc}
\hline & Grignon & La Cape Sud & Lamasquère \\
\hline Sowing & 28 April 2008 & NA & 20 May 2008 \\
Emergence & 11 May 2008 & NA & 29 May 2008 \\
End of growth & 29 June 2008 & NA & 29 July 2008 \\
First yellow leaves & 11 July 2008 & 1 August 2007 & NA \\
Harvest & 9 September 2008 & 11 October & 11 September 2008 \\
Maximal Canopy height $(\mathrm{m})$ & 2.2 & 2.5 & 2.5 \\
Maximal green Leaf Area Index $\left(\mathrm{m}^{2} \mathrm{~m}^{-2}\right)$ & 5.2 & 5.1 & 3.2 \\
Maximal yellow Leaf Area Index $\left(\mathrm{m}^{2} \mathrm{~m}^{-2}\right)$ & 3.6 & 5.1 & NA \\
\hline
\end{tabular}

Over the whole cropping period, the model was very close to measurements with a weak underestimation of ozone fluxes, only $4 \%$ (Fig. 4e). Furthermore, the model reproduced well measurements for each period individually. There were only weak differences between measured and modelled ozone fluxes: $9 \%$ over the bare soil period (Fig. $4 a$ ), $1 \%$ over the growth (Fig. 4b), $2 \%$ during the maturity (Fig. 4c) and $8 \%$ along the senescence period (Fig. 4d). Although measured and modelled total ozone fluxes showed good agreement, the different pathways of deposition, i.e. soil, cuticular and stomatal, may compensate each other. In order to validate ozone partitioning it is necessary to study each deposition pathway individually, as far as possible.
The parameterisation of soil resistance was obtained on the same site and along a range of conditions including bare soil periods before and after maize establishment (Stella et al., 2011). In addition, during the bare soil period, modelled ozone fluxes agreed well with measured ozone fluxes (Fig. 4a), confirming the validity of soil resistance for Grignon site.

The comparison between modelled stomatal conductance for green leaves $\left(g_{\mathrm{s}_{\text {green }}}=1 / R_{\mathrm{S}}^{\text {green }}\right.$, see Sect. 2.3) and stomatal conductance deduced from measurements $\left(g_{\text {scorr }}\right.$, see Sect. 3.2) indicates good agreement between the two estimations (Fig. 5). Since the estimation of $g_{s_{\text {corr }}}$ was inferred from Gross Primary Production, it concerns only leaves able to photosynthesize, i.e. green leaves. Although the two 

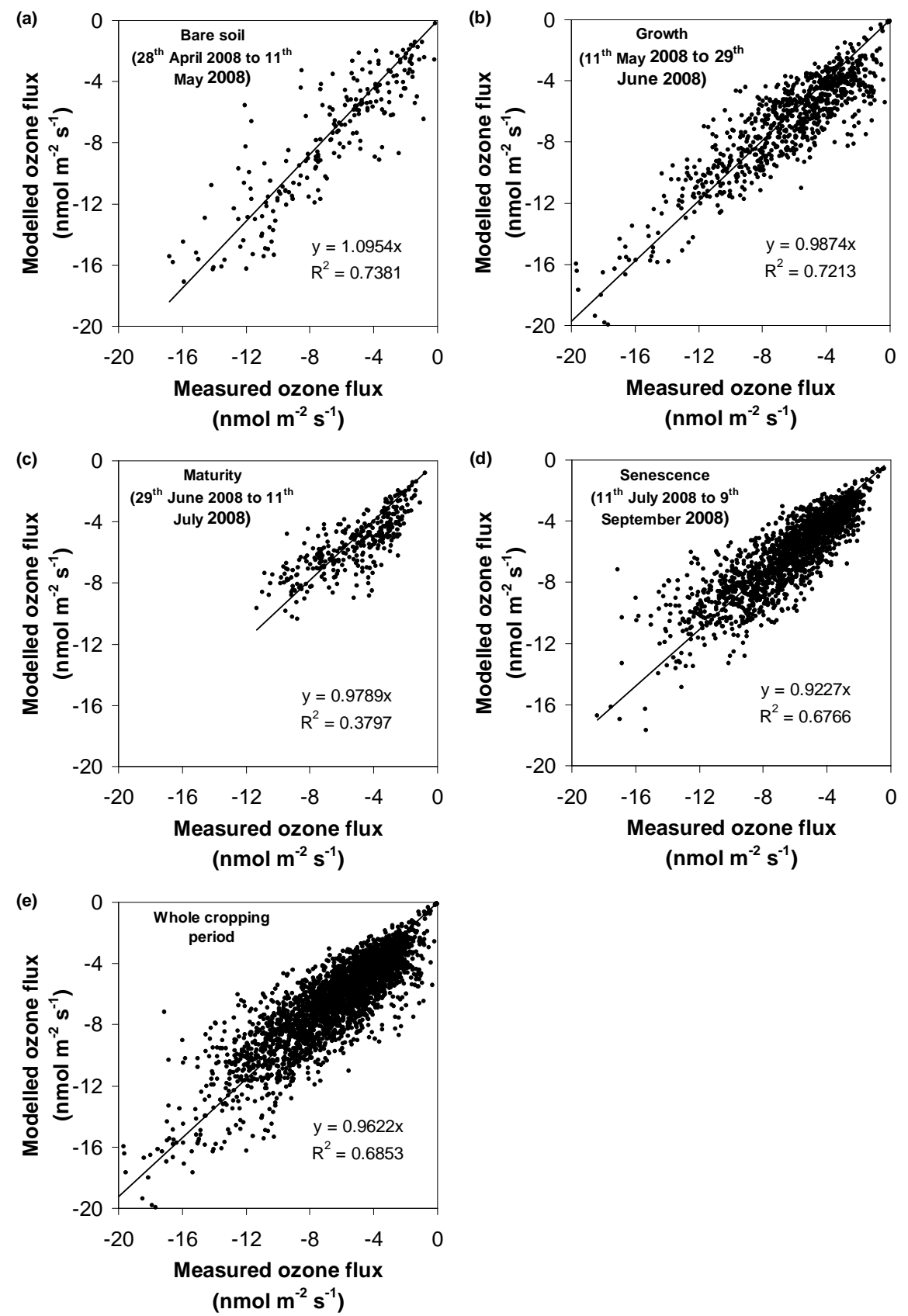

Fig. 4. Comparison between modelled and measured ozone fluxes for the Grignon site during (a) bare soil period, (b) growth, (c) maturity, (d) senescence, and (e) whole cropping period. Only data for $u_{*}>0.1 \mathrm{~m} \mathrm{~s}^{-1}$ are represented.

estimations of stomatal conductance gave similar results, $g_{\mathrm{s}_{\text {corr }}}$ was generally greater than $g_{\mathrm{s}_{\text {green }}}$. As $g_{\mathrm{s}_{\mathrm{corr}}}$ was first deduced from latent heat flux, this overestimation was probably due to soil evaporation which was not fully corrected with a threshold of $60 \%$ on RH by plotting $g_{\text {SPM }}$ against GPP.

No direct estimation of cuticular pathways can be performed, and thus no direct comparison between measured and modelled cuticular conductance can be carried out. But, since the soil and stomatal pathways were validated as indicated previously, the good agreement between modelled and measured ozone fluxes from bare soil to maturity (Figs. 3 and $4 \mathrm{a}-\mathrm{c})$ indicated that the cuticular pathway modelling was satisfactory.

A particular point in the Surfatm- $\mathrm{O}_{3}$ model is the addition of a stomatal conductance for yellow leaves during the senescence period. The dissociation between stomatal conductance for green and yellow leaves means that leaves can transpire without photosynthesizing. Indeed, photosynthesis is an active phenomenon requiring $\mathrm{CO}_{2}$ fixation by enzymes (Romberger et al., 1993) whereas plant transpiration is an 

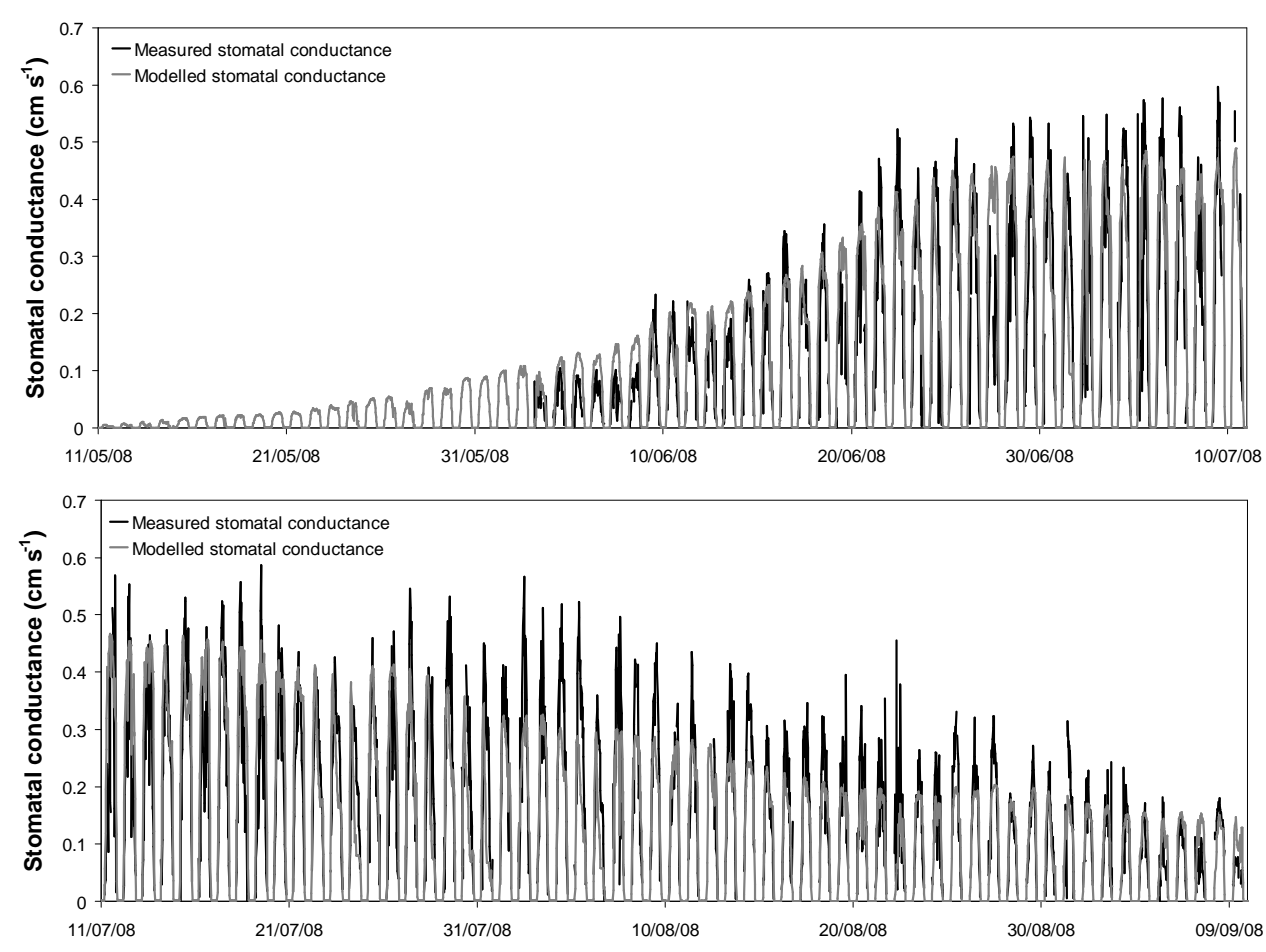

Fig. 5. Time series of stomatal conductance deduced from measurements (black line) and modelled stomatal conductance for green leaves (grey line) for the Grignon site.

inactive phenomenon induced by water potential difference between the substomatal cavities and the air. Such ozone deposition pathway is usually not included in current ozone deposition model. The addition of the yellow leave stomatal conductance pathway improved modelled ozone fluxes during senescence: with this additional pathway, modelled ozone fluxes were close to measurements with a weak difference of only $8 \%$ while the model underestimated measurements by up to $20 \%$ if stomatal conductance for yellow leaves was not included (Fig. 6a). Moreover, the fact that modelled latent heat fluxes including yellow leaves were closer to measurements than without stomatal conductance for yellow leaves confirms the existence of this additional pathway (Fig. 6b). Although previous studies usually focused in stomatal conductance for green leaves and not for senescent leaves, few studies report results of transpiration and photosynthesis rates for yellow leaves in accordance with stomatal opening without photosynthesis. For example, Cayon (2001) showed that leaf transpiration lasted later than leaf photosynthesis. Water Use Efficiency (WUE), the ratio between photosynthesis and transpiration, is also known to decrease with leaf age (Grandjean Grimm and Furhrer, 1992; Adamtey et al., 2010), meaning that photosynthesis decreases earlier than transpiration. Veneklaas and Van den Boogaard (1994) also hypothesized that yellow leaves might lose significant amount of water meaning a stomatal opening. Finally, Hoyaux et al. (2008) found that yellow leaves did not photosynthesize but were still able to respire, which implies stomatal aperture.

\subsection{Model validation on La Cape Sud and Lamasquère sites}

As discussed in the previous section, the Surfatm- $\mathrm{O}_{3}$ model was able to predict ozone fluxes over the whole cropping period, taking into account each deposition pathway, for a maize crop on the Grignon site. However, this model must be tested against measurements carried out in other sites to validate the model and its different parameterisations, or at least found the possible sources of discrepancies. For this, ozone fluxes were modelled with the same parameterisations obtained on the Grignon site and compared with measurements performed over two maize crops on Lamasquère and La Cape Sud sites. The former was characterised by a long growing period without senescence, while the latter had the longest senescent period but no measurements were performed during bare soil and growth periods.

Over the whole period, the before model underestimated ozone fluxes by about $15 \%$ and $18 \%$ on average for La Cape Sud and Lamasquère, respectively (Fig. 7 and Table 3). However, model underestimation was strongly dependent on the phenological stage as indicated in Table 3.

For the Lamasquère site, the model underestimated ozone fluxes by $30 \%$ during bare soil period. During the growth 
Table 3. Mean relative difference between modelled and measured ozone fluxes over different phenological stages for La Cape Sud and Lamasquère sites. Negative values indicate model underestimation and positive values indicate model overestimation.

\begin{tabular}{|c|c|c|c|c|}
\hline & \multicolumn{2}{|c|}{ Lamasquère } & \multicolumn{2}{|c|}{ La Cape Sud } \\
\hline & Period & $\begin{array}{l}\text { Difference between } \\
\text { model and measurements }\end{array}$ & Period & $\begin{array}{c}\text { Difference between } \\
\text { model and measurements }\end{array}$ \\
\hline Bare soil & 20 May to 28 May 2008 & $-30 \%$ & NA & NA \\
\hline Early growth & 29 May to 18 June 2008 & $-33 \%$ & NA & NA \\
\hline Mid growth & 19 June to 8 July 2008 & $-27 \%$ & NA & NA \\
\hline Late growth & 9 July to 29 July 2008 & $-4 \%$ & NA & NA \\
\hline Maturity & 30 July to 11 September 2008 & $-11 \%$ & 26 July to 31 July 2007 & $-20 \%$ \\
\hline Early senescence & NA & NA & 1 August to 23 August 2007 & $-8 \%$ \\
\hline Mid senescence & NA & NA & 24 August to 15 September 2007 & $+6 \%$ \\
\hline Late senescence & NA & NA & 16 September to 11 October 2007 & $-33 \%$ \\
\hline Whole studying period & 20 May to 11 September 2008 & $-18 \%$ & 26 July to 11 October 2007 & $-15 \%$ \\
\hline
\end{tabular}

period, the model underestimated ozone fluxes by $33 \%$ during early growth and $27 \%$ during mid growth, for which LAI did not exceed $1 \mathrm{~m}^{2} \mathrm{~m}^{-2}$. After canopy closure, modelled and measured ozone fluxes showed good agreement with only weak differences of $4 \%$ and $11 \%$ during late growth and maturity respectively (Table 3 ). The fact that Surfatm$\mathrm{O}_{3}$ underestimated the measurements especially during bare soil period and during growing period before canopy closure (when soil deposition is important compared to stomatal and cuticular pathways) suggests that soil resistance $\left(R_{\text {soil }}\right)$ was overestimated for the Lamasquère site. Thus, it seems that values of $R_{\text {soil } \min }$ and/or $k_{\text {soil }}$ obtained on Grignon site by Stella et al. (2011) are site specific and depend on soil characteristics such as porosity, texture and organic matter content. Indeed, the sensitivity analysis carried out on soil parameters exhibited a large sensitivity to $k_{\text {soil }}$ and $R_{\text {soil }}$ min (Table 4 , see Sect. 4.4). After canopy closure, the ground deposition is less important due to high in-canopy aerodynamic resistance. Thus, total ozone deposition is less sensitive to an overestimation of soil resistance for fully developed canopy (Table 4). This explains the good agreement between modelled and measured ozone fluxes for late growth and maturity.

Concerning La Cape Sud site, modelled ozone fluxes agreed with measurements from maturity to mid senescence with difference between model and measurements of $8 \%$ and $6 \%$ during early and mid senescence respectively (Table 3). This supports the need to include stomatal conductance for yellow leaves during senescence, as proposed for the Grignon site. During maturity, the model underestimated ozone fluxes by $20 \%$. However, only few data were available during maturity (i.e. 5 days) which did not allow deriving fair conclusions. Moreover, this strong difference was only due to particular daytime conditions with very high vapour pressure deficit during early afternoon. Under these conditions, stomatal resistance was overestimated because of an overestimated impact of VPD upon $g_{\max }$ by $g_{\mathrm{VPD}}$ function. During late senescence, the model strongly underestimated ozone fluxes, about $33 \%$ in mean (Table 3 ) but this could reach up to $200 \%$. It is possible to hypothesise that VOCs emitted by senescent leaves reacted with ozone, leading to a stronger measured ozone fluxes for the La Cape Sud site. For example, Karl et al. (2003) measured peak in acetone and acetaldehyde emissions during autumn above a mixed hardwood forest, attributed to senescing biomass. It is well known that VOCs emissions are dependant on temperature. Concerning our study, the largest difference between measured and modelled ozone fluxes occurred for air temperature around $15^{\circ} \mathrm{C}$ (data not shown). This result is consistent with VOCs emissions between $12^{\circ} \mathrm{C}$ and $23^{\circ} \mathrm{C}$ reported by Baker et al. (2001), Schade et al. (2001) and Karl et al. (2002). Thus, since Surfatm- $\mathrm{O}_{3}$ model does not include ozone chemistry, modelled ozone fluxes were underestimated.

\subsection{Sensitivity analysis of the Surfatm-O3 model}

The sensitivity analysis was carried out on $k_{\text {soil }}, R_{\text {soil }}$ min,$k_{\text {cut }}$, $R_{\text {cut } \max }$, and $g_{\text {max }}$. In order to take account of the influence of environmental variables on resistances to ozone deposition, four representative climatic conditions were tested (sunny day, overcast day, clear night and overcast night). In addition, because the weight of each deposition pathway is different according to the phenological stage (see Sect. 4.5), for each climatic condition three development stages with different canopy height and leaf index area were simulated. The results, expressed as relative difference from the reference case (i.e. with parameterisations indicated in Sect. 2), are summarized in Table 4.

The sensitivity to parameters of soil resistance decreases with canopy development while the sensitivity to parameters of cuticular and stomatal resistances increases with canopy development. Indeed, the contributions of stomatal and cuticular sinks to total ozone deposition increase with leaf index area whereas this latter provokes an increase of incanopy aerodynamic resistance, which lowers the contribution of the soil pathway in the $\mathrm{O}_{3}$ sink. 
Table 4. Response of modelled ozone fluxes to parameters of ozone deposition resistances. Blank cases correspond to relative differences lower than $1 \%$. Bold cases correspond to the reference values. The reference height is $3.2 \mathrm{~m}$.

\begin{tabular}{|c|c|c|c|c|c|c|c|c|c|c|c|c|}
\hline \multirow{4}{*}{$\begin{array}{l}h_{\mathrm{c}}(\mathrm{m}) \\
\mathrm{LAI}\left(\mathrm{m}^{2} \mathrm{~m}^{-2}\right)\end{array}$} & \multicolumn{3}{|c|}{ Sunny day } & \multicolumn{3}{|c|}{ Overcast day } & \multicolumn{3}{|c|}{ Clear night } & \multicolumn{3}{|c|}{ Overcast night } \\
\hline & \multicolumn{2}{|c|}{$\begin{array}{c}R_{\mathrm{n}}=500 \mathrm{~W} \mathrm{~m}^{-2} \\
T_{\mathrm{a}}=30^{\circ} \mathrm{C}\end{array}$} & \multirow{3}{*}{$\begin{array}{c}u=4 \mathrm{~m} \mathrm{~s}^{-1} \\
\mathrm{RH}=60 \% \\
h_{\mathrm{c}}=2.5 \\
\mathrm{LAI}=5\end{array}$} & \multicolumn{2}{|c|}{$\begin{array}{c}R_{\mathrm{n}}=200 \mathrm{~W} \mathrm{~m}^{-2} \\
T_{\mathrm{a}}=15^{\circ} \mathrm{C}\end{array}$} & \multirow{3}{*}{$\begin{array}{c}u=10 \mathrm{~m} \mathrm{~s}^{-1} \\
\mathrm{RH}=80 \% \\
h_{\mathrm{c}}=2.5 \\
\mathrm{LAI}=5\end{array}$} & \multicolumn{2}{|c|}{$\begin{array}{c}R_{\mathrm{n}}=-50 \mathrm{~W} \mathrm{~m}^{-2} \\
T_{\mathrm{a}}=10^{\circ} \mathrm{C}\end{array}$} & \multirow{3}{*}{$\begin{array}{c}u=1 \mathrm{~m} \mathrm{~s}^{-1} \\
\mathrm{RH}=70 \% \\
h_{\mathrm{c}}=2.5 \\
\mathrm{LAI}=5\end{array}$} & \multicolumn{2}{|c|}{$\begin{array}{c}R_{\mathrm{n}}=-50 \mathrm{~W} \mathrm{~m}^{-2} \\
T_{\mathrm{a}}=5^{\circ} \mathrm{C}\end{array}$} & \multirow{3}{*}{$\begin{array}{r}u=6 \mathrm{~m} \mathrm{~s}^{-1} \\
\mathrm{RH}=90 \% \\
h_{\mathrm{c}}=2.5 \\
\mathrm{LAI}=5\end{array}$} \\
\hline & $h_{\mathrm{c}}=0$ & $h_{\mathrm{c}}=1$ & & $h_{\mathrm{c}}=0$ & $h_{\mathrm{c}}=1$ & & $h_{\mathrm{c}}=0$ & $h_{\mathrm{c}}=1$ & & $h_{\mathrm{c}}=0$ & $h_{\mathrm{c}}=1$ & \\
\hline & $\mathrm{LAI}=0$ & $\mathrm{LAI}=2$ & & $\mathrm{LAI}=0$ & $\mathrm{LAI}=2$ & & $\mathrm{LAI}=0$ & $\mathrm{LAI}=2$ & & $\mathrm{LAI}=0$ & $\mathrm{LAI}=2$ & \\
\hline \multicolumn{13}{|c|}{ Parameters of soil resistance } \\
\hline \multicolumn{13}{|l|}{$k_{\mathrm{soil}}^{1}$} \\
\hline 0.018 & $+52 \%$ & $+28 \%$ & $+8 \%$ & $+57 \%$ & $+35 \%$ & $+14 \%$ & $+11 \%$ & $+5 \%$ & $+1 \%$ & $+59 \%$ & $+35 \%$ & $+12 \%$ \\
\hline 0.024 & Ref & Ref & Ref & Ref & Ref & Ref & Ref & Ref & Ref & Ref & Ref & Ref \\
\hline 0.030 & $-38 \%$ & $-23 \%$ & $-9 \%$ & $-38 \%$ & $-24 \%$ & $-11 \%$ & $-15 \%$ & $-7 \%$ & $-2 \%$ & $-40 \%$ & $-25 \%$ & $-12 \%$ \\
\hline \multicolumn{13}{|l|}{$R_{\text {soil }}^{1}$} \\
\hline 15.75 & $+23 \%$ & $+14 \%$ & $+4 \%$ & $+28 \%$ & $+17 \%$ & $+7 \%$ & $+6 \%$ & $+3 \%$ & - & $+26 \%$ & $+16 \%$ & $+6 \%$ \\
\hline 21 & Ref & Ref & Ref & Ref & Ref & Ref & Ref & Ref & Ref & Ref & Ref & Ref \\
\hline 26.25 & $-16 \%$ & $-10 \%$ & $-4 \%$ & $-18 \%$ & $-11 \%$ & $-5 \%$ & $-5 \%$ & $-2 \%$ & - & $-17 \%$ & $-11 \%$ & $-5 \%$ \\
\hline \multicolumn{13}{|c|}{ Parameters of cuticular resistance } \\
\hline \multicolumn{13}{|l|}{$k_{c u t}^{2}$} \\
\hline $\begin{array}{l}\text { cut } \\
0.03\end{array}$ & - & - & - & - & $-3 \%$ & $-6 \%$ & - & - & $-16 \%$ & - & $-12 \%$ & $-21 \%$ \\
\hline 0.045 & Ref & Ref & Ref & Ref & Ref & Ref & Ref & Ref & Ref & Ref & Ref & Ref \\
\hline 0.06 & - & - & - & - & $+4 \%$ & $+8 \%$ & - & - & $+19 \%$ & - & $+19 \%$ & $+34 \%$ \\
\hline \multicolumn{13}{|l|}{$R_{\text {cut }}^{3}$} \\
\hline 2500/LAI & - & $+7 \%$ & $+16 \%$ & - & $+13 \%$ & $+24 \%$ & - & $+18 \%$ & $+65 \%$ & - & $+29 \%$ & $+57 \%$ \\
\hline 5000/LAI & Ref & Ref & Ref & Ref & Ref & Ref & Ref & Ref & Ref & Ref & Ref & Ref \\
\hline 10000/LAI & - & $-3 \%$ & $-8 \%$ & - & $-6 \%$ & $-12 \%$ & - & $-11 \%$ & $-36 \%$ & - & $-15 \%$ & $-30 \%$ \\
\hline \multicolumn{13}{|c|}{ Parameter of stomatal resistance } \\
\hline \multicolumn{13}{|l|}{$g_{\max }$ for $\mathrm{O}_{1}^{1}$} \\
\hline 117 & - & $-5 \%$ & $-11 \%$ & - & $-5 \%$ & $-10 \%$ & - & - & - & - & - & - \\
\hline 156 & Ref & Ref & Ref & Ref & Ref & Ref & Ref & Ref & Ref & Ref & Ref & Ref \\
\hline 195 & - & $+5 \%$ & $+11 \%$ & - & $+5 \%$ & $+10 \%$ & - & - & - & - & - & - \\
\hline
\end{tabular}

1: the interval corresponds to $\pm 25 \%$ of the reference value (Ref); ${ }^{2}$ : the interval corresponds to maximal and minimal values reported by Lamaud et al. (2009); ${ }^{3}$ : the interval corresponds to the uncertainty reported by Massman (2004).

The impact of climatic conditions is less clear. Indeed, we have chosen to performed this sensitivity analysis using micrometeorological classes (sunny day, overcast day, clear night and overcast night) implying that several climatic variables changes simultaneously (e.g. wind speed, temperature, relative humidity and radiation). Moreover, any variation in these climatic variables not only changes soil, cuticular and stomatal resistances to ozone deposition, but also transfer resistances (i.e. aerodynamic resistance, quasi-laminar boundary layer resistance and in-canopy canopy resistance). However, patterns can be distinguished. Overall, the sensitivity to soil parameters is greater during overcast conditions and the sensitivity to cuticular parameters is greater during nighttime.

For bare soil periods, the model is particularly sensitive to $k_{\text {soil }}$. A change of $25 \%$ of $k_{\text {soil }}$ can lead to up to $50 \%$ increase when $k_{\text {soil }}$ decreased in modelled ozone flux. The sensitivity to $R_{\text {soil }_{\text {min }}}$ is smaller: $25 \%$ of variation of this term lead to a change of modelled flux of around $30 \%$ during bare soil to less than $1 \%$ during fully developed canopy, the flux increasing when $R_{\text {soil }_{\text {min }}}$ decreased.

The sensitivity to the cuticular resistance parameters is the largest during nighttime when canopy is fully developed.
The model is mostly sensitive to $R_{\text {cut }}$ max which is also the term with the greatest uncertainty. The flux increased when $R_{\text {cut }_{\max }}$ decreased. Its variation in the range reported by Massman (2004) can lead to a change of $65 \%$ during clear night. The sensitivity to $k_{\text {cut }}$ is comparatively small: in the range of uncertainty reported by Lamaud et al. (2009), $k_{\text {cut }}$ induces changes of modelled ozone flux between less than $1 \%$ and $34 \%$ for the cases considered.

The stomatal resistance parameter $g_{\max }$ is responsible for a weak variation of modelled ozone flux: $25 \%$ of variation of $g_{\max }$ lead to a maximum $11 \%$ variation of modelled flux. However, only this parameter was tested here and several others can lead to variation of stomatal resistance such as the parameters of the attenuation functions described in Sect. 2.3 and Table 1.

According to this sensitivity analysis, weak changes in ozone resistance parameters induce large deviations of modelled ozone fluxes. However, the variability of modelled fluxes is strongly dependent on canopy development stages and to a lower extent to climatic conditions. Thus, the fact that the model reproduces ozone fluxes whatever the development stage and whatever the climatic conditions provide evidence of the robustness of the Surfatm- $\mathrm{O}_{3}$ model. 

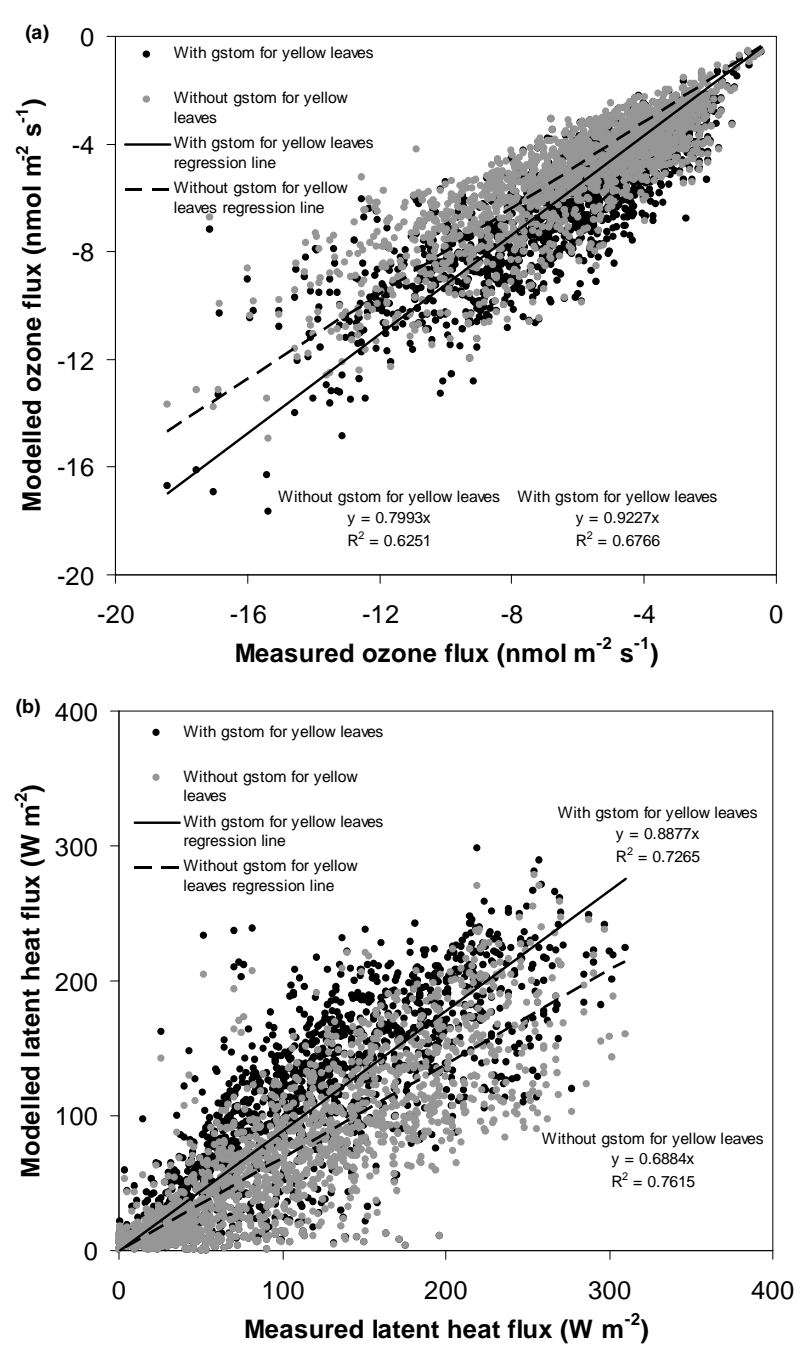

Fig. 6. Comparison between measured and modelled (a) ozone and (b) latent heat fluxes including (black symbols) and without including (grey symbols) stomatal conductance for yellow leaves in the model for the Grignon site during senescence (i.e. from 11 July 2008 to 9 September 2008). Only data for $u_{*}>0.1 \mathrm{~m} \mathrm{~s}^{-1}$ are represented.

\subsection{Ozone flux partitioning}

The Surfatm- $\mathrm{O}_{3}$ model can be used to partition total ozone flux in soil, cuticular and stomatal pathways. This section is dedicated to ozone flux partitioning and its analysis along the cropping season for Grignon, Lamasquère and La Cape Sud maize crops. However, the model was not able to fully reproduce measurements during early growth at Lamasquère site and during late senescence at La Cape Sud site. Modelling these two stages needs further development. Thus, ozone partitioning during these two periods could be subject to few discrepancies.

On a daily basis, non-stomatal deposition (i.e. soil and cuticular) represented the major sink of ozone for the three
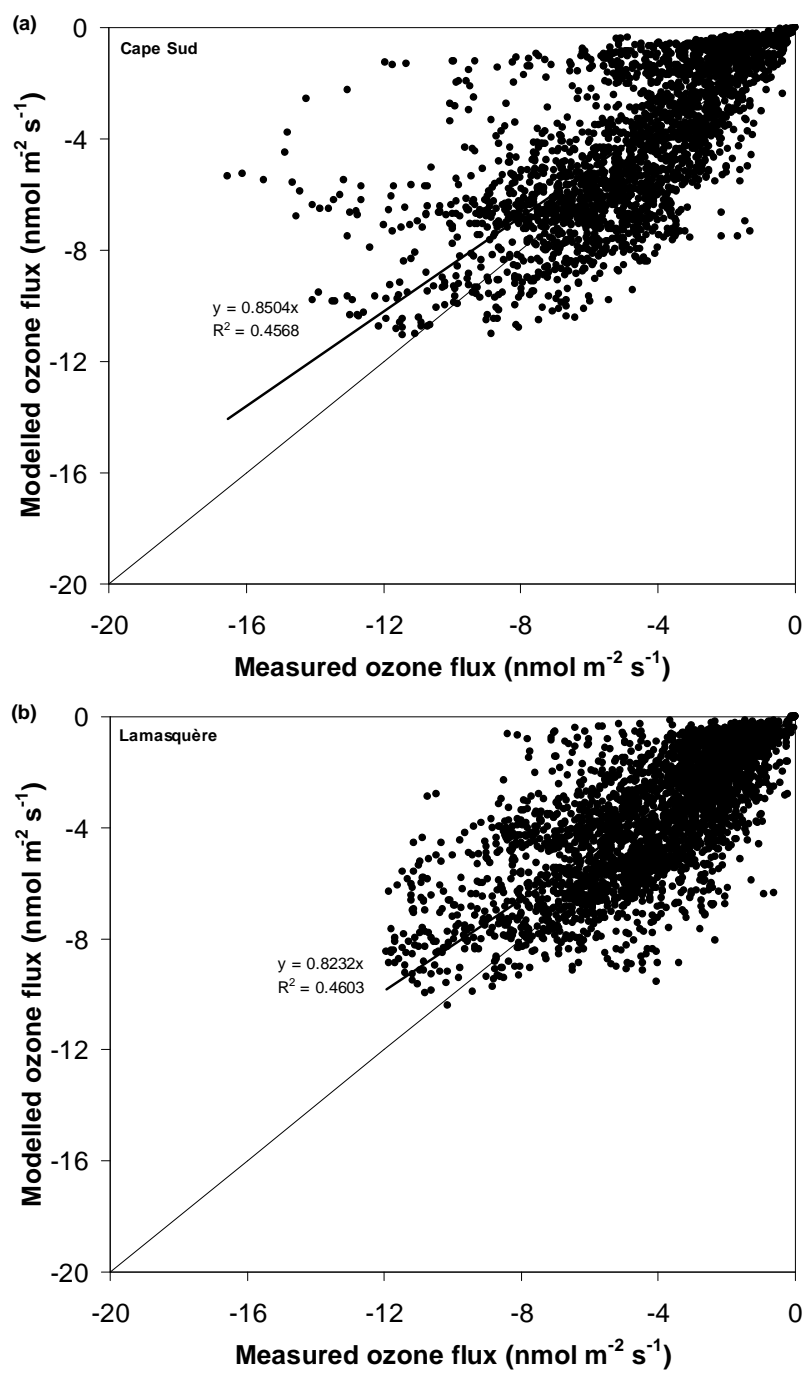

Fig. 7. Comparison between measured and modelled ozone fluxes over the whole studying period for (a) La Cape Sud site and (b) Lamasquère site. Only data for $u_{*}>0.1 \mathrm{~m} \mathrm{~s}^{-1}$ are represented.

sites for any development stage (Figs. 8a, 9a and 10a). For Grignon and Lamasquère, non-stomatal deposition represented the only deposition pathway during bare soil period and it progressively decreased with maize development to around $70 \%$ (Fig. 8a) and $80 \%$ (Fig. 9a) respectively. For La Cape Sud, non-stomatal flux was around $70 \%$ of the total ozone flux during maturity and raise to around $80 \%$ before harvest (Fig. 10a). Concerning the partitioning of the before non-stomatal pathway, soil deposition was the main deposition pathway during bare soil and early growth, but its contribution progressively decreased with maize development to the benefit of cuticular deposition. This evolution was due to the increase in LAI which, on the one hand, increased incanopy aerodynamic resistance, thus decreased soil deposition, and on the other hand decreased cuticular resistance, allowing cuticular deposition to increase. The partitioning of 
(a)

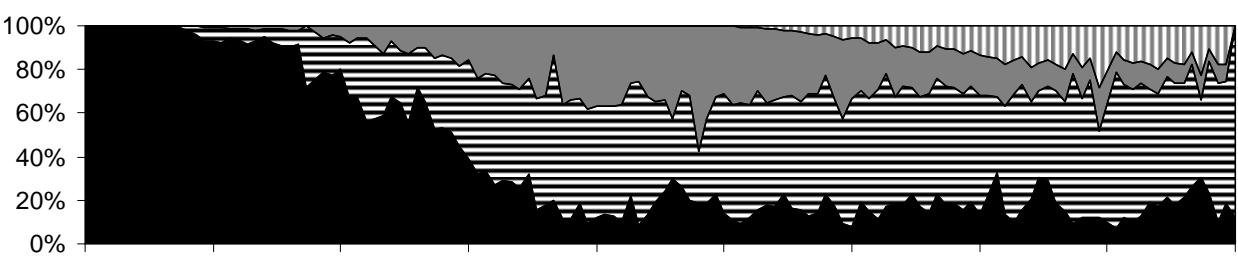

(b)

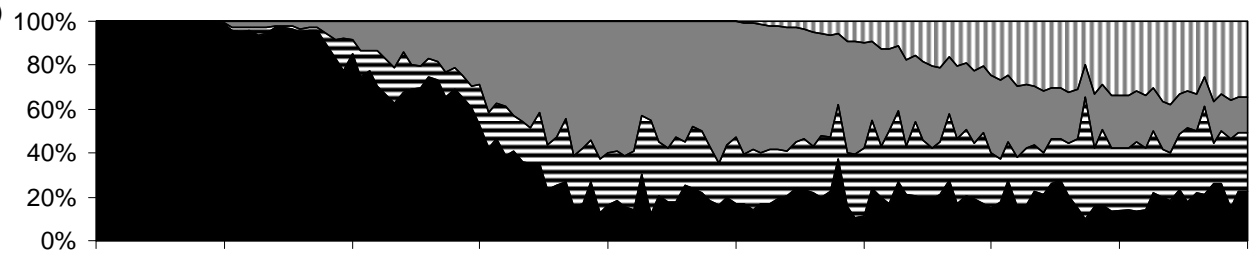

(c)

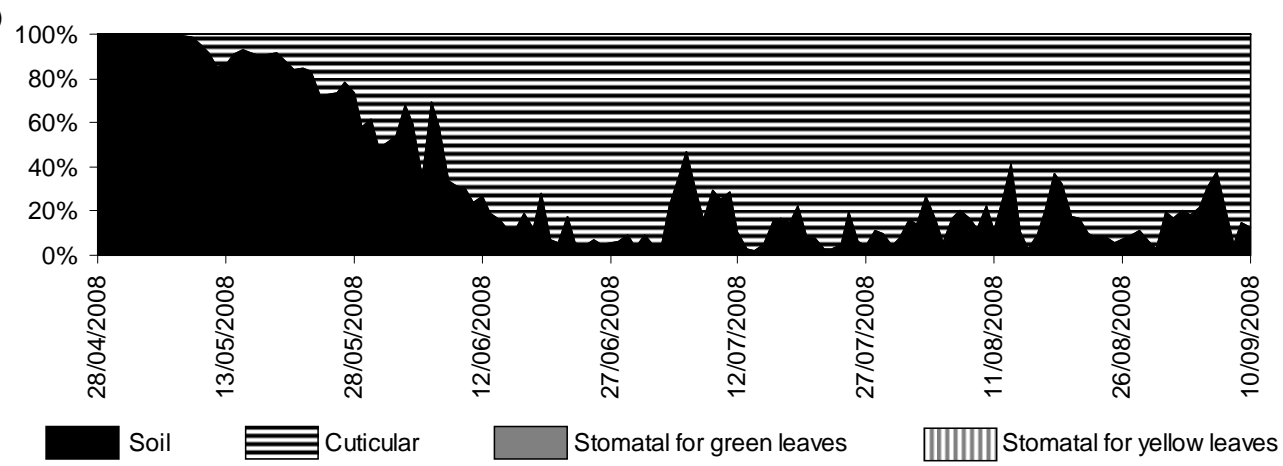

Fig. 8. Mean (a) daily, (b) diurnal and (c) nocturnal relative contributions of soil, cuticular, stomatal for green leaves, and stomatal for yellow leaves pathways to total ozone flux over the whole study period for the Grignon site.

non-stomatal deposition was different for the three sites, especially when maize canopy was fully developed: for both Grignon (Fig. 8a) and La Cape Sud (Fig. 10a) sites, soil and cuticular pathways were around $20 \%$ and $50 \%$ of the total ozone deposition whereas they were similar, each around $40 \%$ for Lamasquère site (Fig. 9a). As previously, the difference of contribution of soil and cuticular deposition in the non-stomatal sink between the three sites was due to difference of LAI between each site. Indeed, Lamasquère site had the lowest LAI (Table 2) which provided the lowest $R_{\mathrm{ac}}$ and thus the strongest contribution of soil deposition. Moreover, it also allowed a lower cuticular deposition than the two other sites.

The contribution of stomatal deposition was dependent on plant development and progressively increased along the growing season to reach its maximal contribution during maturity. Except for Lamasquère, for which maize was harvested before any yellow leaves appeared, the stomatal deposition to yellow leaves increased along the senescence while the contribution of green leaves decreased. On the daily average, stomatal deposition did not represent the major sink for ozone, with a mean contribution of only $20-30 \%$ for each site (Figs. 8a, 9a and 10a). The contribution of stomatal deposition of yellow leaves could represent a non negligible part on the total ozone flux, and could reach up to $20 \%$ of the total flux for Grignon and La Cape Sud.

Ozone partitioning and the relative contribution of each sink were highly dependent on the time in the day. During daytime, stomatal deposition represented on average half of the total deposition when maize was fully developed for Grignon (Fig. 8b) and La Cape Sud (Fig. 10b). For Lamasquère, the low LAI induced that stomatal pathway represented in average less than $40 \%$ of the total ozone deposition during daytime. The contributions of stomatal deposition given previously are only averages. Indeed, during daytime, stomatal deposition was linked to stomatal aperture: this sink represented only a small part of total deposition at sunrise and sunset, while it could reach $75 \%$ for Grignon and La Cape Sud and $60 \%$ for Lamasquère of the total ozone deposition during the maximal physiological activity of the maize in the day. The contribution of stomatal pathway was particularly visible on La Cape Sud site. Indeed, the dynamic of ozone flux (Fig. 2g), and more clearly of ozone deposition velocity (Fig. 2h), was due to stomatal component. On this site with low air relative humidity (Fig. 2c), the high air evaporative demand induced stomatal closure at midday which induced a decrease in stomatal flux, and thus in total ozone flux. Of course, during nighttime non-stomatal pathway was 
(a)

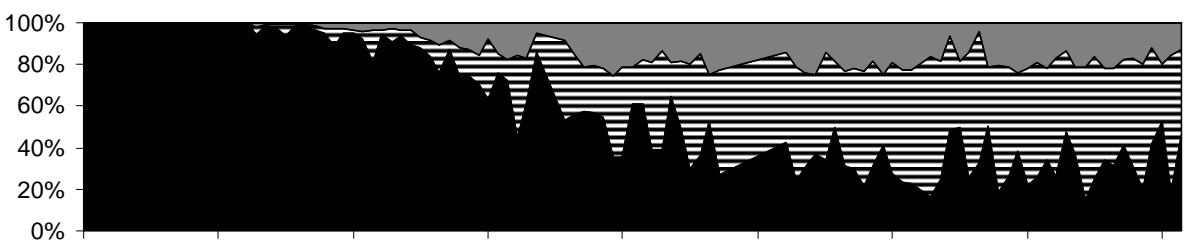

(b)

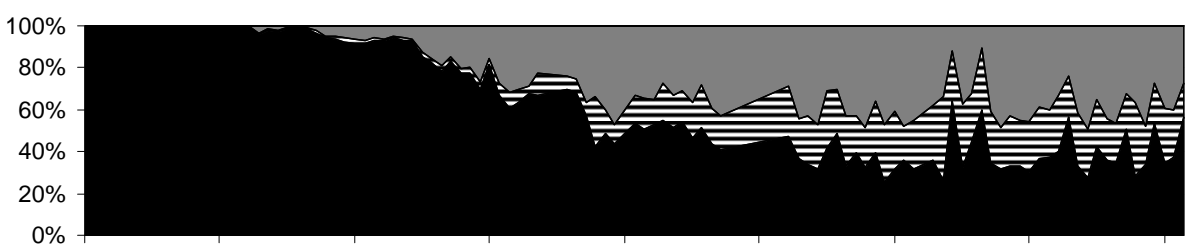

(c)

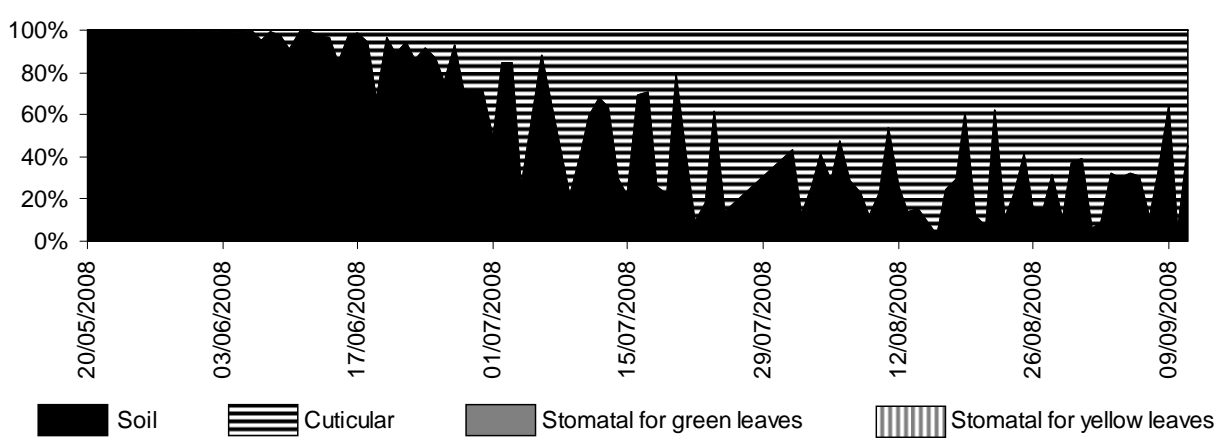

Fig. 9. As in Fig. 8, but for the Lamasquère site.

the only deposition pathway (Figs. 8c, 9c and 10c). Cuticular deposition represented the main nocturnal deposition pathway when canopy was fully developed for Grignon (Fig. 8c) and La Cape Sud (Fig. 10c), around $90 \%$. This strong contribution of the cuticular pathway to total nocturnal deposition from maize maturity was due to the high relative humidity during nighttime which both enhanced cuticular deposition (Zhang et al., 2002; Lamaud et al., 2009) and diminished soil deposition. For Lamasquère, the contribution of cuticular deposition during the night was lower than for Grignon and La Cape Sud due to its low LAI influencing conversely soil and cuticular pathways, as explained previously. However, the contributions of soil and cuticular pathways for this site were highly variables due to the variability of climatic conditions at the Lamasquère site (Fig. 9c).

Few studies reported ozone flux partitioning between stomatal and non-stomatal pathways, the former inferred from measurement of stomatal conductance and ozone concentration and the latter obtained by difference between total and stomatal ozone fluxes. Partitioning between stomatal and non-stomatal sinks in this study was similar to those reported by several authors. For example, Fares et al. (2011) found that, for a pine forest, annual non-stomatal flux represented between $33 \%$ and $50 \%$ of the total ozone flux, and could reach up to $65 \%$ according to season. Gerosa et al. $(2005,2009)$ reported very strong contribution of diurnal non-stomatal pathway which could reach up to $70 \%$ for Mediterranean forest and maquis ecosystem, while nonstomatal deposition could represent only $30 \%$ for barley field (Gerosa et al. 2004). Unfortunately, previous studies rarely reported partitioning of stomatal (i.e. for green and yellow leaves) and non-stomatal (i.e. soil and cuticular) pathways.

\section{Summary and conclusions}

This study presented the Surfatm- $\mathrm{O}_{3}$ model. It includes (i) an energy budget model simulating latent (LE) and sensible $(H)$ heat fluxes and (ii) a pollutant exchange model simulating ozone fluxes between the surface and the atmosphere. The aim of this model is to predict total ozone deposition to agroecosystems along the whole cropping season, i.e. taking into account bare soil, growth, maturity, and senescence, and to partition ozone deposition in stomatal, soil and cuticular pathways.

This model was developed for a maize crop near Paris with parameterisations of soil and cuticular resistances for ozone obtained on the same site, but including other datasets. The model agreed well with measured ozone fluxes for each development stage. During senescence, an additional ozone sink was added: a stomatal sink for yellow leaves. Without 
(a)

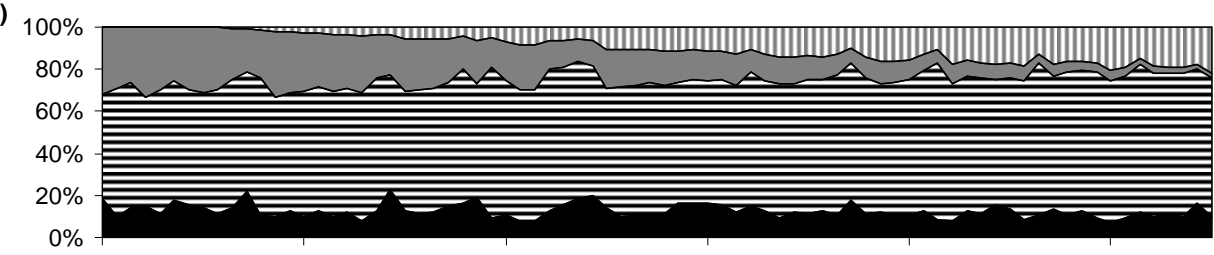

(b)

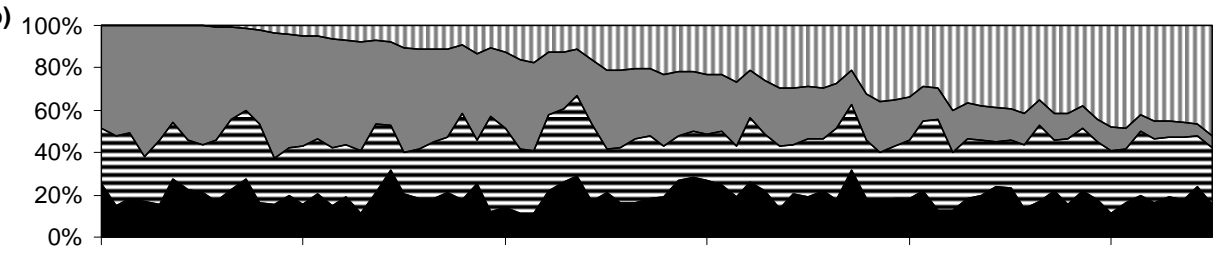

(c)

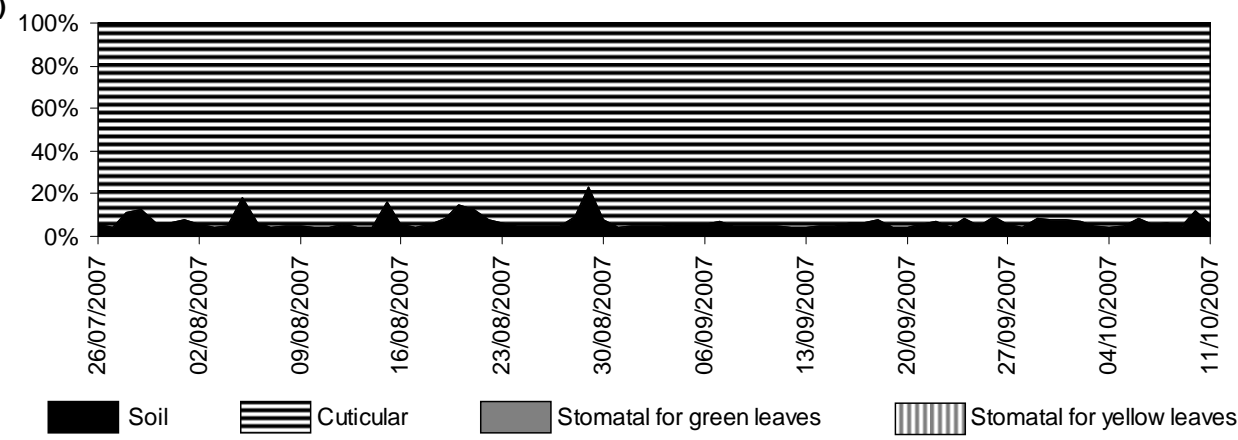

Fig. 10. As in Fig. 8, but for the La Cape Sud site.

this additional pathway, ozone fluxes were underestimated. The presence of the stomatal resistance for yellow leaves was confirmed by the latent heat flux, this latter indicating that transpiration was maintained in spite of maize senescence. Over the whole cropping period, modelled and measured ozone fluxes differed by only $4 \%$. Model validation was performed to two other maize crops in South of France. The modelled fluxes agreed well with measurements from late growth to mid senescence, but underestimated measurements during bare soil, early growth and late senescence. This discrepancy was attributed on the one hand to soil parameterisation which seems to be site-specific, and on the other hand to possible chemical reactions between ozone and volatile organic compounds emitted by plants during late senescence. However, over the whole period, model was able to relatively well predict ozone fluxes for the two sites, with model underestimation of $15 \%$ and $18 \%$ for each site.

The sensitivity analysis was carried out on key parameters of soil, cuticular and stomatal resistances to ozone deposition. This analysis showed that weak changes in ozone resistance parameters induce large deviations of modelled ozone fluxes. However, the variability of modelled fluxes is strongly dependent on canopy development stages and to a lower extent to climatic conditions: the sensitivity to parameters was the strongest for soil resistance during bare soil period and early growth while changes in cuticular and stomatal resistances induced important changes when the canopy was fully developed. The sensitivity analysis tends to demonstrate the robustness of the Surfatm- $\mathrm{O}_{3}$ model since it reproduced ozone fluxes from sowing to harvest in spite of few discrepancies attributed to site-specific soil resistance and possible chemical reactions.

The analysis of ozone flux partitioning revealed that nonstomatal sink was the main contributor to ozone deposition. It represented the only deposition pathway during bare soil period and between $70 \%$ and $80 \%$ in mean during maize maturity. However, the relative contribution of non-stomatal pathway to total ozone deposition could be very low, especially during optimal environmental conditions for plant growth where stomatal flux was $60 \%$ to $75 \%$ of the total ozone flux. The weight of each deposition pathway in total ozone deposition was particularly dependent on canopy structure, especially the Leaf Area Index.

A new model of ozone deposition was thus proposed to predict and partition ozone deposition taking into account each development stage from sowing to harvest. However this model was only tested on maize crops, although this analysis was carried out for three sites in different geographical regions. The next step of this work is to validate this model for different soils and crops such as wheat or barley. 
Since it is able to predict both total ozone deposition and ozone absorbed through stomata by vegetation, the Surfatm$\mathrm{O}_{3}$ model could represent a new support to improve projections of atmospheric ozone budget, and to predict crop yield losses due to ozone.

Acknowledgements. This work was supported by the European commission through two projects CarboEurope-IP and NitroEurope-IP, a french regional funding R2DS (Région Ile-deFrance), a french-german project PHOTONA (CNRS/INSU/DFG) and a French national project Vulnoz (ANR, VMC). Eric Larmanou, Olivier Fanucci, Brigitte Durand, Céline Decuq, Michel Burban, Pascal Duprix, Sandra Debesa, Didier Garrigou, Hervé Gibrin, Nicole Ferroni, Bernard Marciel and Alain Kruszewski are greatly acknowledged for their assistance in maintenance of the experimental site, data acquisition and proceeding, and for their help in the field and in the workshop. The authors also gratefully acknowledge Bernard Defranssu, Dominique Tristant and Jean-Pierre de Saint-Stéban from the experimental farm of AgroParisTech Grignon and Michel Gay and Benoit Cantaloube from the experimental farm of Lamothe for leaving the access to their fields.

Edited by: S. Reis

\section{References}

Adamtey, N., Cofie, O., Ofosu-Budu, K. G., Ofosu-Anim, J., Laryea, K. B., and Forster, D.: Effect of N-enriched co-compost on transpiration efficiency and water-use efficiency of maize (Zea maize L.) under controlled irrigation, Agr. Water. Manage., 97, 995-1005, 2010.

Ahmad, Z., Allam, I. M., and Aleem, B. J.: Effect of environmental factors on the atmospheric corrosion of mild steel in aggressive coastal environment, Anti-Corros. Method. M., 47, 215$225,2000$.

Ainsworth, E.A.: Rice production in a changing climate: a metaanalysis of responses to elevated carbon dioxide an elevated ozone concentration, Glob. Change. Biol., 14, 1642-1650, 2008.

Almeida, E., Marracos, M., Morcillo, M., and Rosales, B.: Atmospheric corrosion of mild steel, Part I - Rural and urban atmosphere, Mater. Corros., 51, 859-864, 2000.

Altimir, N., Tuovinen, J. P., Vesala, T., Kulmala, M., and Hari, P.: Measurements of ozone removal by Scots pine shoots: calibration of a stomatal uptake model including the non stomatal component, Atmos. Environ., 38, 2387-2398, 2004.

Altimir, N., Kolari, P., Tuovinen, J.-P., Vesala, T., Bäck, J., Suni, T., Kulmala, M., and Hari, P.: Foliage surface ozone deposition: a role for surface moisture?, Biogeosciences, 3, 209-228, doi:10.5194/bg-3-209-2006, 2006.

Ashmore, M. R.: Assessing the future global impacts of ozone on vegetation, Plant. Cell. Environ., 28, 949-964, 2005.

Ashmore, M., Toet, S., and Emberson, L.: Ozone - a significant threat to future world food production, New. Phytol., 170, 201204, 2006.

Aubinet, M., Grelle, A., Ibrom, A., Rannik, U., Moncrieff, J., Foken, T., Kowalski, A. S., Martin, P. H., Berbigier, P., Bernhofer, C., Clement, R., Elbers, J., Granier, A., Grunwald, T., Morgenstern, K., Pilegaard, K., Rebmann, C., Snijders, W., Valentini,
R., and Vesala, T.: Estimates of the annual net carbon and water exchange of forests: The EUROFLUX methodology, Adv. Ecol. Res., 30, 113-175, 2000.

Avnery, S., Mauzerall, D. L., Liu, J., and Horowitz, L. W.: Global crop yield reductions due to surface ozone exposure: 1. Year 2000 crop production losses and economic damage. Atmos. Environ., 45, 2284-2296, 2011a.

Avnery, S., Mauzerall, D. L., Liu, J., and Horowitz, L. W.: Global crop yield reductions due to surface ozone exposure: 2. Year 2030 potential crop production losses and economic damage under two scenarios of $\mathrm{O}_{3}$ pollution, Atmos. Environ., 45, 22972309, 2011b.

Baker, B., Guenther, A., Greenberg, J., and Fall, R.: Canopy level fluxes of 2-metyl-3-buten-2-ol, acetone and methanol by a portable relaxed eddy accumulation system, Environ. Sci. Technol., 35, 1701-1708, 2001.

Bassin, S., Calanca, P., Weidinger, T., Gerosa, G., and Fuhrer, J.: Modeling seasonal ozone fluxes to grassland and wheat: model improvement, testing, and application, Atmos. Environ., 38, 2349-2359, 2004.

Bell, M. L., Dominici, F., and Samet, J. M.: A meta-analysis of time series studies of ozone and mortality with comparison to the National Morbidity, Mortality, and Air Pollution Study, Epidemiology, 16, 436-445, 2005.

Béziat, P., Ceschia, E., and Dedieu, G.: Carbon balance of a three crop succession over two cropland sites in South West France, Agr. Forest Meteorol., 149, 1628-1645, 2009.

Boyce, A., Nord, A. G., and Tronner, K.: Atmospheric bronze and copper corrosion as an environmental indicator, Water. Air. Soil. Poll., 127, 193-205, 2001.

Cayon, S.: The evolution of photosynthesis, transpiration and chlorophyll during the development of leaves of plantain (Musa AAB Simmonds), Infomusa, 10, 12-15, 2001.

Cieslik, S.: Ozone fluxes over various plant ecosystems in Italy: A review, Environ. Pollut., 157, 1487-1496, 2009.

Coyle, M., Nemitz, E., Storeton-West, R., Fowler, D., and Cape, J. N.: Measurements of ozone deposition to a potato canopy, Agr. Forest Meteorol., 149, 655-666, 2009.

Emberson, L. D., Ashmore, M. R., Cambridge, H. M., Simpson, D., and Tuovinen, J. P.: Modelling stomatal ozone flux across Europe, Environ. Pollut., 109, 403-413, 2000a.

Emberson, L. D., Simpson, D., Tuovinen, J. P., Ashmore, M. R., and Cambridge, H. M.: Towards a model of ozone deposition and stomatal uptake over Europe, EMEP/MSC-W Note 6/2000, Norwegian Meteorological Institute, Oslo, available at: www. emep.int/reports/dnmi_note_6_2000.pdf, 2000b.

Fares, S., McKay, M., Holzinger, R., and Goldstein, A. H.: Ozone fluxes in a Pinus ponderosa ecosystem are dominated by nonstomatal processes: Evidence from long-term continuous measurements, Agr. Forest Meteorol., 150, 420-431, 2010.

Felzer, B. S., Cronin, T., Reilly, J. M., Melillo, J. M., and Wang, X.: Impacts of ozone on trees and crops, C. R. Geosci., 339, 784-798, 2007.

Forster, P., Ramaswamy, V., Artaxo, P., Berntsen, T., Betts, R., Fahey, D. W., Haywood, J., Lean, J., Lowe, D. C., Myhre, G., Nganga, J., Prinn, R., Raga, G., Schulz, M., and Van Dorland, R.: Changes in Atmospheric Constituents and in Radiative Forcing, in: Climate Change 2007: The Physical Basis, edited by: Solomon, S., Qin, D., Manning, M., Chen, Z., Marquis, M., Av- 
eryt, K. B., Tignor, M., and Miller, H. L., Contribution of Working Group I to Fourth Assessment Report of IPCC on Climate Change, Cambridge University Press, Cambridge, UK/NY, USA, 2007.

Fowler, D., Pilegaard, K., Sutton, M.A., Ambus, P., Raivonen, M., Duyzer, J., Simpson, D., Fagerli, H., Fuzzi, S., Schjoerring, J. K., Granier, C., Neftel, A., Isaksen, I. S. A., Laj, P., Maione, M., Monks, P. S., Burkhardt, J., Daemmgen, U., Neirynck, J., Personne, E., Wichink-Kruit, R., Butterbach-Bahl, K., Flechard, C., Tuovinen, J. P., Coyle, M., Gerosa, G., Loubet, B., Altimir, N., Gruenhage, L., Ammann, C., Cieslik, S., Paoletti, E., Mikkelsen, T. N., Ro-Poulsen, H., Cellier, P., Cape, J. N., Horvath, L., Loreto, F., Niinemets, U., Palmer, P. I., Rinne, J., Misztal, P., Nemitz, E., Nilsson, D., Pryor, S., Gallagher, M. W., Vesala, T., Skiba, U., Brüggemann, N., Zechmeister-Boltenstern, S., Williams, J., O’Dowd, C., Facchini, M. C., de Leeuw, G., Flossman, A., Chaumerliac, N., and Erisman, J. W.: Atmospheric composition change: Ecosystems-Atmosphere interactions, Atmos. Environ., 43, 5193-5267, 2009.

Gallagher, M. W., Beswick, K. M., and Coe, H.: Ozone dry deposition to coastal waters, Q. J. Roy. Meteor. Soc., 127, 539-558, 2001.

Gerosa, G., Marzuoli, R., Cieslik, S., and Ballarin-Denti, A.: Stomatal ozone fluxes over barley field in Italy, "Effective exposure" as a possible link between exposure- and flux-based approaches, Atmos. Environ., 38, 2421-2432, 2004.

Gerosa, G., Vitale, M., Finco, A., Manes, F., Ballarin-Dentin, A., and Cieslik, S.: Ozone uptake by an evergreen Mediterranean Forest (Quercus ilex) in Italy - Part I: Micrometeorological flux measurements and flux partitioning, Atmos. Environ., 39, 32553266, 2005.

Gerosa, G., Derghi, F., and Cieslik, S.: Comparison of different algorithms for stomatal ozone flux determination from micrometeorological measurements, Water. Air. Soil. Poll., 179, 309-321, 2007.

Gerosa, G., Finco, A., Mereu, S., Marzuoli, R., and Ballarin-Denti, A.: Interactions among vegetation and ozone, water and nitrogen fluxes in a coastal Mediterranean maquis ecosystem, Biogeosciences, 6, 1783-1798, doi:10.5194/bg-6-1783-2009, 2009.

Grandjean Grimm, A. and Fuhrer, J.: The response of spring wheat (Triticum aestivum L.) to ozone at higher elevations, III. Response of leaf and canopy gas exchange, and chlorophyll fluorescence to ozone flux, New. Phytol., 122, 321-328, 1992.

Grantz, D. A., Zhang, X. J., Massman, W. J., Den Hartog, G., Neumann, H. H., and Pederson, J. R.: Effects of stomatal conductance and surface wetness on ozone deposition in field-grown grape, Atmos. Environ., 29, 3189-3198, 1995.

Grantz, D. A., Zhang, X. J., Massman, W. J., Delany, A., and Pederson, J. R.: Ozone deposition to a cotton (Gossypium hirsutum L.) field: stomatal and surface wetness effects during the California Ozone Deposition Experiment, Agr. Forest Meteorol., 85, 19-31, 1997.

Hazucha, M. J. and Lefohn, A. S.: Nonlinearity in human health response to ozone: Experimental laboratory considerations, Atmos. Environ., 41, 4559-4570, 2007.

Hoyaux, J., Moureaux, C., Tourneur, D., Bodson, B., and Aubinet, M.: Extrapolating gross primary productivity from leaf to canopy scale in winter wheat crop, Agr. Forest Meteorol., 148, 668-679, 2008.
Ito, K., De Leon, S. F., and Lippmann, M.: Associations between ozone and daily mortality: Analysis and meta-analysis, Epidemiology, 16, 446-457, 2005.

Jones, H. G.: Plants and Microclimate: A quantitative approach to environmental plant physiology, 2nd Edn., Cambridge University Press, Cambridge, UK, 1992.

Karl, T. G., Spirig, C., Rinne, J., Stroud, C., Prevost, P., Greenberg, J., Fall, R., and Guenther, A.: Virtual disjunct eddy covariance measurements of organic compound fluxes from a subalpine forest using proton transfer reaction mass spectrometry, Atmos. Chem. Phys., 2, 279-291, doi:10.5194/acp-2-279-2002, 2002.

Karl, T. G., Guenther, A., Spirig, C., Hansel, A., and Fall, R.: Seasonal variation of biogenic VOC emissions above a mixed hardwood forest in northern Michigan, Geophys. Res. Lett., 30, 2186, doi:10.1029/2003GL018432, 2003.

Kowalski, S., Sartore, M., Burlett, R., Berbigier, P., and Loustau, D.: The annual carbon budget of a French pine forest (Pinus Pinaster) following harvest, Glob. Change. Biol., 9, 1051-1065, 2003.

Kowalski, S., Loustau, D., Berbigier, P., Manca, G., Tedeschi, V., Borghetti, M., Valentini, R., Kolari, P., Berniger, F., Rannik, U., Hari, P., Rayment, M., Mencuccini, M., Moncrieff, J., and Grace, J.: Paired comparison of carbon exchange between undisturbed and regenerating stands in four managed forests in Europe, Glob. Change. Biol., 10, 1707-1723, 2004.

Lamaud, E., Carrara, A., Brunet, Y., Lopez, A., and Druilhet, A.: Ozone fluxes above and within a pine forest canopy in dry and wet conditions, Atmos. Environ., 36, 77-88, 2002.

Lamaud, E., Loubet, B., Irvine, M., Stella, P., Personne, E., and Cellier, P.: Partitioning of ozone deposition over a developed maize crop between stomatal and non-stomatal uptakes, using eddy-covariance flux measurements and modelling, Agr. Forest Meteorol., 149, 1385-1386, 2009.

Lee, D. S., Holland, M. R., and Falla, N.: The potential effect of ozone on materials in the UK, Atmos. Environ., 30, 1053-1065, 1996.

Lehuger, S., Gabrielle, B., Cellier, P., Loubet, B., Roche, R., Béziat, P., Ceschia, E., and Wattenbach, M.: Predicting the net carbon exchanges of crop rotations in Europe with an agro-ecosystem model, Agr. Ecosyst. Environ., 139, 384-395, 2010.

Levy, J. I., Chemerynski, S. M., and Sarnat, J. A.: Ozone exposure and mortality: an empiric Bayes metaregression analysis, Epidemiology, 16, 458-468, 2005.

Loubet, B., Laville, P., Lehuger, S., Larmanou, E., Fléchard, C., Mascher, N., Genermont, S., Roche, R., Ferrara, R., Stella, P., Personne, E., Durand, B., Decuq, C., Flura, D., Masson, S., Fanucci, O., Rampon, J. N., Siemens, J., Kindler, R., Gabrielle, B., Schrumpf, M., and Cellier, P.: Carbon, nitrogen and Greenhouse gases budgets over a four years crop rotation in northern France, Plant. Soil., 343, 109-137, 2011.

Massey, S. W.: The effects of ozone and $\mathrm{NO}_{\mathrm{x}}$ on the deterioration of calcareous stone, Sci. Total. Environ., 227, 109-224, 1999.

Massman, W. J.: Toward an ozone standard to protect vegetation based on effective dose: a review of deposition resistances and possible metric, Atmos. Environ., 38, 2323-2337, 2004.

Meehl, G. A., Stocker, T. F., Collins, W. D., Friedlingstein, P., Gaye, A. T., Gregory, J. M., Kitoh, A., Knutti, R., Murphy, J. M., Noda, A., Raper, S. C. B., Watterson, I. G., Weaver, A. J., and Zhao, Z. C.: Global climate projections, in: Climate Change 2007: The 
Physical Basis, edited by: Solomon, S., Qin, D., Manning, M., Chen, Z., Marquis, M., Averyt, K. B., Tignor, M., and Miller, H. L., Contribution of Working Group I to Fourth Assessment Report of IPCC on Climate Change, Cambridge University Press, Cambridge, UK/NY, USA, 2007.

Monteith, J. L.: Evaporation and surface temperature, Q. J. Roy. Meteorol. Soc., 107, 1-27, 1981.

Muller, J. B. A., Percival, C. J., Gallagher, M. W., Fowler, D., Coyle, M., and Nemitz, E.: Sources of uncertainty in eddy covariance ozone flux measurements made by dry chemiluminescence fast response analysers, Atmos. Meas. Tech., 3, 163-176, doi:10.5194/amt-3-163-2010, 2010.

Paoletti, E.: Ozone slows stomatal response to light and leaf wounding in a Mediterranean evergreen broadleaf, Arbustus unedo, Environ. Pollut., 134, 439-445, 2005.

Paoletti, E. and Grulke, N. E.: Does living in elevated $\mathrm{CO}_{2}$ ameliorate tree response to ozone? A review on stomatal response, Environ. Pollut., 137, 483-493, 2005.

Personne, E., Loubet, B., Herrmann, B., Mattsson, M., Schjoerring, J. K., Nemitz, E., Sutton, M. A., and Cellier, P.: SURFATMNH3: a model combining the surface energy balance and bidirectional exchanges of ammonia applied at the field scale, Biogeosciences, 6, 1371-1388, doi:10.5194/bg-6-1371-2009, 2009.

PORG: Ozone in the United Kingdom: Fourth Report of the Photochemical Oxidants Review Group, 1997.

Rastogi, S. K., Gupta, B. N., Husain, T., Chandra, H., Mathur, N., Pangtey, B. S., Chandra, S. V., and Grag, N.: A cross-sectional study of pulmonary function among workers exposed to multimetals in the glass bangle industry, Am. J. Ind. Med., 20, 391399, 1991.

Rochette, P., Pattey, E., Desjardins, R. L., Dwyer, L. M., Stewart, D. W., and Dubé, P. A.: Estimation of maize (Zea mays L.) canopy conductance by scaling up leaf stomatal conductance, Agr. Forest Meteorol., 54, 241-261, 1991.

Romberger, J. A., Hejnowicz, Z., and Hill, J. F.: Plant structure: function and development, with special reference to woody plants, The Blackburn press, Caldwell, USA, 1993.

Schade, G. W. and Goldstein, A. H.: Fluxes of oxygenated volatile organic compounds from a ponderosa pine plantation, J. Geophys. Res., 106, 3111-3123, 2001.

Sitch, S., Cox, P. M., Collins, W. J., and Huntingford, C.: Indirect radiative forcing of climate change through ozone effects on the land-carbon sink, Nature, 448, 791-795, 2007.

Stella, P., Lamaud, E., Brunet, Y., Bonnefond, J.-M., Loustau, D., and Irvine, M.: Simultaneous measurements of $\mathrm{CO}_{2}$ and water exchanges over three agroecosystems in South-West France, Biogeosciences, 6, 2957-2971, doi:10.5194/bg-6-2957-2009, 2009.
Stella, P., Loubet, B., Lamaud, E., Laville, P., and Cellier, P.: Ozone deposition onto bare soil: a new parameterisation, Agr. Forest Meteorol., 151, 669-681, 2011.

Targer, I. B., Balmes, J., Lurmann, F., Ngo, L., Alcorn, S., and Kunzli, N.: Chronic exposure to ambient ozone and lung function in young adults, Epidemiology, 16, 751-759, 2005.

Tuovinen, J. P., Ashmore, M. R., Emberson, L. D., and Simpson, D.: Testing and improving the EMEP ozone deposition module, Atmos. Environ., 38, 2373-2385, 2004.

Tuzet, A., Perrier, A., Loubet, B., and Cellier, P.: Modelling ozone deposition fluxes: The relative roles of deposition and detoxification processes, Agr. Forest Meteorol., 151, 480-492, 2011.

Uysal, N. and Schapira, R. M.: Effects of ozone on lung function and lung diseases, Curr. Opin. Pulm. Med., 9, 144-150, 2003.

Van Pul, W. A. J. and Jacobs, A. F. G.: The conductance of a maize crop and the underlying soil to ozone under various environmental conditions, Bound. Lay. Meteorol., 69, 83-99, 1994.

Veneklaas, E. and Van den Boogaard, R.: Leaf age-structure effects on plant water use and photosynthesis of two wheat cultivars, New. Phytol., 128, 331-337, 1994.

Vingarzan, R.: A review of surface ozone background levels and trends, Atmos. Environ., 38, 3431-3442, 2004.

Vitale, M., Gerosa, G., Ballarin-Denti, A., and Manes, F.: Ozone uptake by an evergreen Mediterranean Forest (Quercus ilex) in Italy - Part II: flux modelling. Upscaling leaf to canopy ozone uptake by a process-based model, Atmos. Environ., 39, 32673278, 2005.

Wesely, M. L.: Parameterization of surface resistance to gaseous dry deposition in regional-scale numerical models, Atmos. Environ., 23, 1293-1304, 1989.

Wesely, M. L. and Hicks, B. B.: A review of the current status of knowledge on dry deposition, Atmos. Environ., 34, 2261-2282, 2000.

Wild, O.: Modelling the global tropospheric ozone budget: exploring the variability in current models, Atmos. Chem. Phys., 7, 2643-2660, doi:10.5194/acp-7-2643-2007, 2007.

Wittig, V. E., Ainsworth, E. A., Naidu, S. L., Karnosky, D. F., and Long, S. P.: Quantifying the impact of current and future tropospheric ozone on tree biomass, growth, physiology and biochemistry: a quantitative meta-analysis, Glob. Change. Biol., 15, 396-424, 2009.

Zhang, L., Brook, J. R., and Vet, R.: On ozone dry deposition with emphasis on non-stomatal uptake and wet canopies, Atmos. Environ., 36, 4787-4799, 2002.

Zhang, L., Vet, R., Brook, J. R., and Legge, A. H.: Factors affecting stomatal uptake of ozone by different canopies and a comparison between dose and exposure, Sci. Total. Environ., 370, 117-132, 2006. 